\title{
REPORT ON A JAPANESE RESEARCH PERIOD FOR THE DENDROLOGICAL ATLAS PROJECT JUNE 1-SEPTEMBER 30, 2013
}

\author{
I. RÁCZ \\ Department of Botany, Hungarian Natural History Museum \\ H-1476 Budapest,.Pf. 222, Hungary; iracz@bot.nbmus.hu
}

\begin{abstract}
Following up on previous researches made in Japan from mid-September to late November 1997, the purpose of the author's 2013 trip was to complete the documentation of the temperate-zone gymnosperms of Japan for the ongoing Dendrological Atlas Project. A full documentation of 35 conifer taxa could be accomplished. Overall, the work included the field explorations of these conifers, documenting the species, their associated vegetation, and rendering additional study and documentation of the native woody flora in various living collections in Kyoto, Osaka, Tokyo, and Tsukuba.
\end{abstract}

Key words: dendroflora, Dendrological Atlas, gymnosperms, Japan

\section{INTRODUCTION}

The Dendrological Atlas Project was established by Zsolt Debreczy at the Natural History Museum, Budapest, with a vision of an illustrated manual based on Alfred Rehder's classical work, the Manual of Cultivated Trees and Shrubs (1934). This work is still the best summary of the (cold)hardy dendroflora known in Rehder's time, approximately the first third of the 20th century. He delimited his flora to cultivated trees and shrubs hardy in North America but with a worldwide scope. It is the only work which presents identification keys and full descriptions of 2,350 species (with a brief description of an additional 1,265 species and 507 hybrids), all in 498 genera and 113 families of woody plants of the temperate and adjacent zones. No manual made an effort to provide such a clear and comprehensive account of the Arcto- and Madro-Tertiary (and Antarcto-Cretaceous, see DebreczY and RÁCZ 2011) flora(s) than Rehder did. The keys guide the reader through flora(s) with plants/genera either independent and widely separated, or closely related but widely separated, during epochs of vegetation history. The "analytical keys" as Rehder himself called his keys are complementary to the concise descriptions of species and are a great help to the reader's easier orientation to this vast flora (REHDER 1934). There are two areas where Rehder's manual appeared to fall short; it has no illustrations, and (since its keys are mostly based on herbarium specimens) he could not combine the 
morphological characters in a way that the discussed taxa would not only reflect characters typical in their native habitats, but also those growing in cultivation, in "horticulturally ideal" circumstances.

With its 50 conifer taxa (of which 33 are endemic), Japan has been an important part of the Atlas project. Japan hosts almost one-tenth of the temperate conifer taxa (DEBRECZY and RÁCZ 2000, 2011), and - depending on taxonomy and the delimitation of flora - ca 500 broad-leaved woody species are major components of the plant associations in the conifer habitats.

The Dendrological Atlas expedition to Japan in 1997 was organised in collaboration with the International Dendrological Research Institute, Inc. (IDRI Inc., US), with Zsolt Debreczy as Principal Investigator, and Earthwatch, Center for Field Research (Watertown, Massachusetts, US). DAP team member István Rácz from the Botanical Department, Hungarian Natural History Museum was hosted by the project; Mikio Kaji, Director of the Tokyo University Forest in Hokkaido and his colleague Hiromitsu Kisanuki acted as project advisors (Earthwatch 1996). The work was organised under the auspices of the university, and the Rokugo student hostel served as the venue for the base camp for two 2-week periods with international volunteers from Japan, US, France, Singapore, Malaysia, and our invited guest from Abkhazia) (Figs 2-4). Before and after these research periods, which concentrated on documenting all gymnosperms in their natural associations in Hokkaido, the team of Zs. Debreczy and I. Rácz, together with K. Musial, Curator of Living Collections at the Huntington Botanical Gardens, San Marino, California, were able to explore other conifer areas in Japan (Fig. 1). Main points of these brief expeditions were the Tokyo University Forest in Chichibu, the Yatsugatake (range), Yakushima World Natural Heritage Site, Amami Islands and other conifer-inhabited sites on Tanigawadake, Nantaishan, Mt Fuji, Mt Daisen, Odaigahara Mts, Mt Kirishima, and Toi Peninsula. In Hokkaido, most of the conifer and habitat documentation occurred in the Tokyo University Forest in Daisetsuzan National Park, as well as in Mt Apoi and other areas of the Hokkaido coastline. This first expedition to Japan resulted in a complete documentation of 21 conifer taxa, and partial documentation of another 14 conifers (Appendix).

In 2012 the Kyoto University Museum accepted a grant application of DAP team member István Rácz to continue research for the Dendrological Atlas Project for a 4-month period. The work plan included the project outline and the explanation why an additional research period was needed. The museum, with botany professor Hidetoshi Nagamasu, had offered its institutional help in securing a work facility and arranging research and collecting permits and field logistics. Specifically, a study of 24 (or possibly more, mostly endemic/subendemic) conifers native to Japan, and the documentation of their habitats were scheduled in this collaboration. 


\section{WORK IN THE HERBARIUM OF THE KYOTO UNIVERSITY MUSEUM}

The first phase of the research period in Kyoto was largely a 3-week study of the gymnosperms in the herbarium of the Kyoto University Museum. Here, consulting about 400 herbarium specimens made it possible to collect data of morphological details and geographic distribution of selected species and varieties of conifers. Occurrence data helped to pinpoint the best locations for several rare, local, and in-part endangered conifers in Japan. The latter task needed the

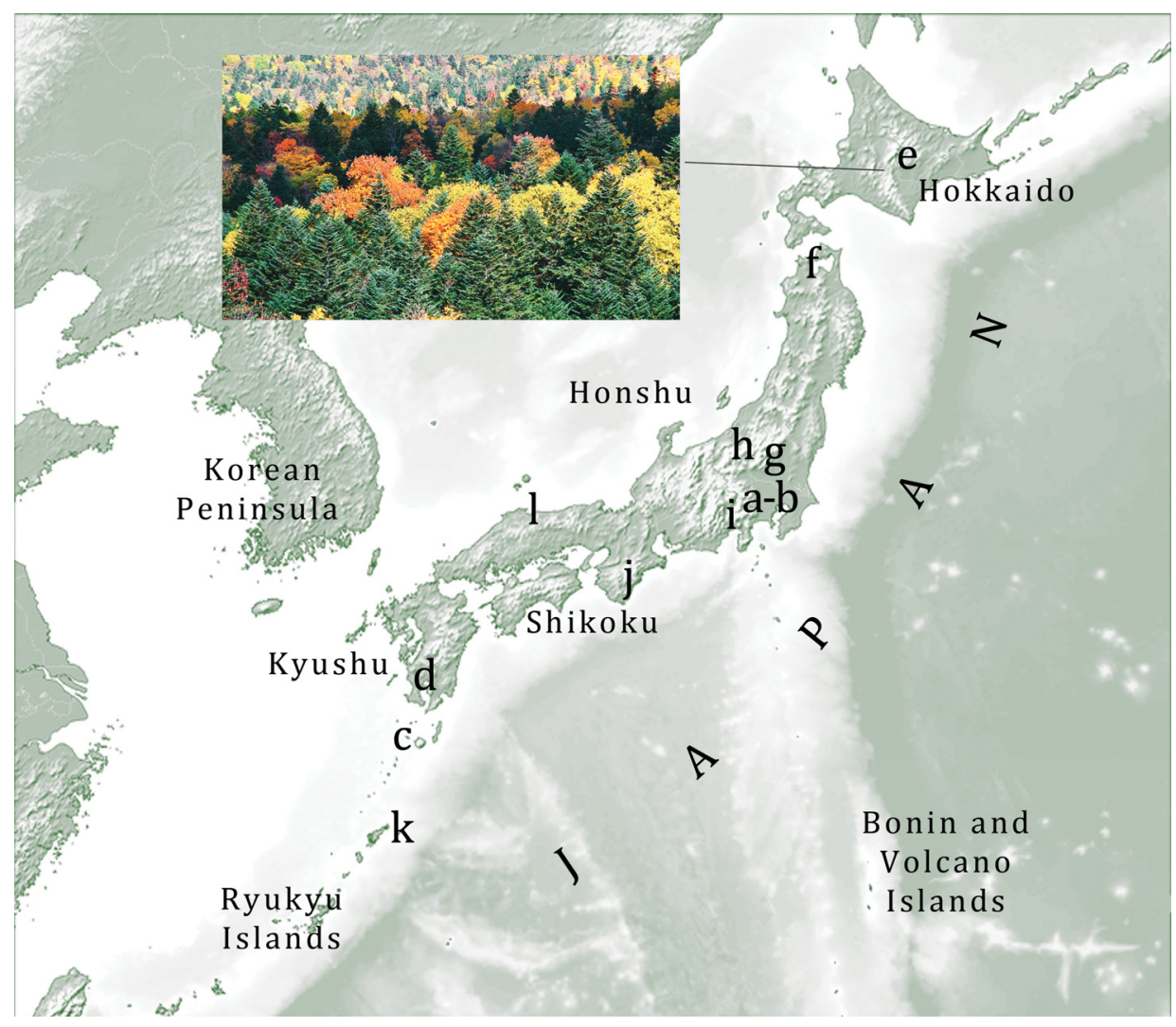

Fig. 1. Main areas of conifer documentation during the first Dendrological Atlas expedition (Sep. 1-Nov. 26, 1997). Inset: the general (autumn) view of mixed forests near the base camp. Base map source: http://en.wikipedia.org/wiki/Outline_of_Japan\#mediaviewer/File:Topographic_Map_ of Japan.png. $\mathrm{a}-\mathrm{b}$ - preparations in Tokyo and work in the Chichibu mountains; $\mathrm{c}, \mathrm{d}$ - work in Yaku-shima and in mainland Kyushu; e - work with Earthwatch volunteers in central Hokkaido; $\mathrm{f}$ - documenting conifers in the environs of Aomori; $\mathrm{g}$ - work in the environs of Nikko (Chusenjiko, Mt Nantai, Senjogahara); h - Mt Tanigawa; i - Mt Fuji; j - Kii Peninsula (Odaigahara Mts); $\mathrm{k}$ - Amami Island; 1 - Mt Dai-sen. 


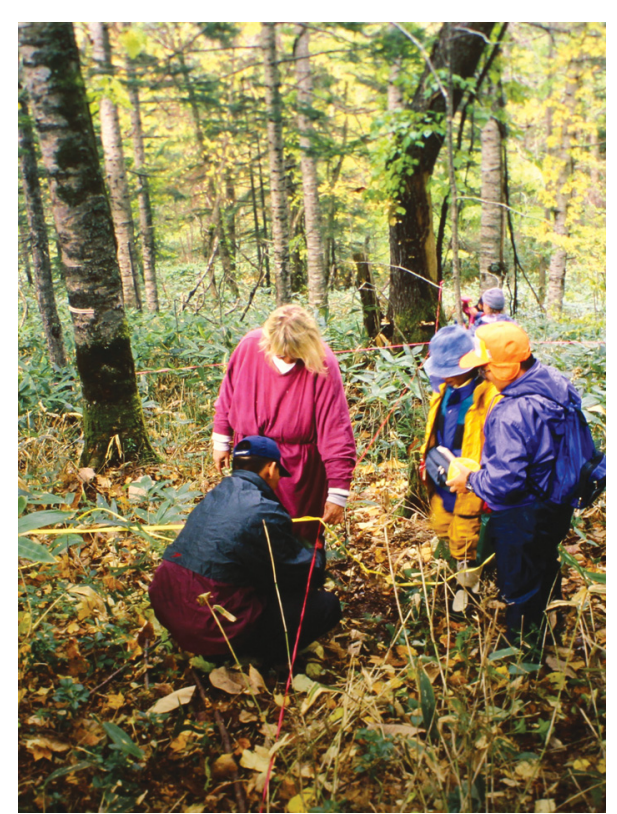

Fig. 2. Volunteers setting up a synecological quadrant in a mixed forest of Abies sachalinensis (near Rokugo, Hokkaido).

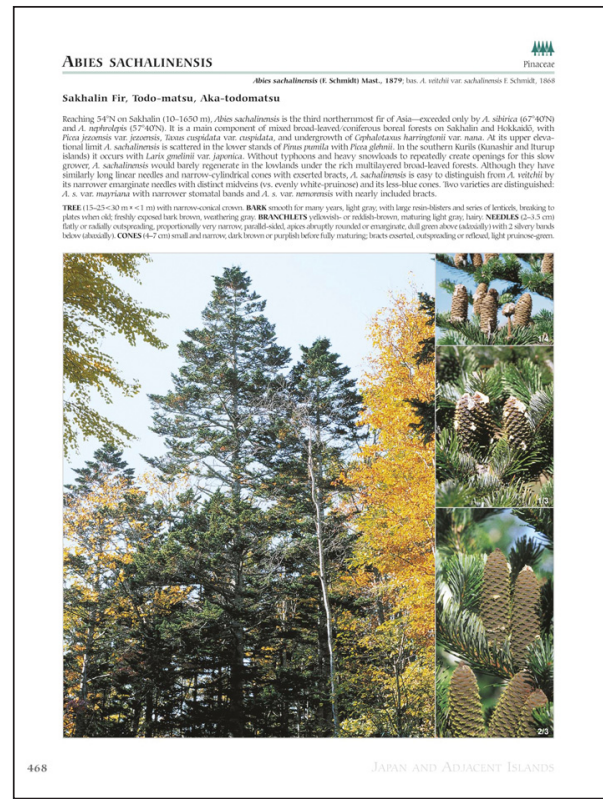

Fig. 3. Species profile of Abies sachalinensis as it appears in DeBRECZY and RÁcz (2011), based on work in the forest shown in Figure 2.

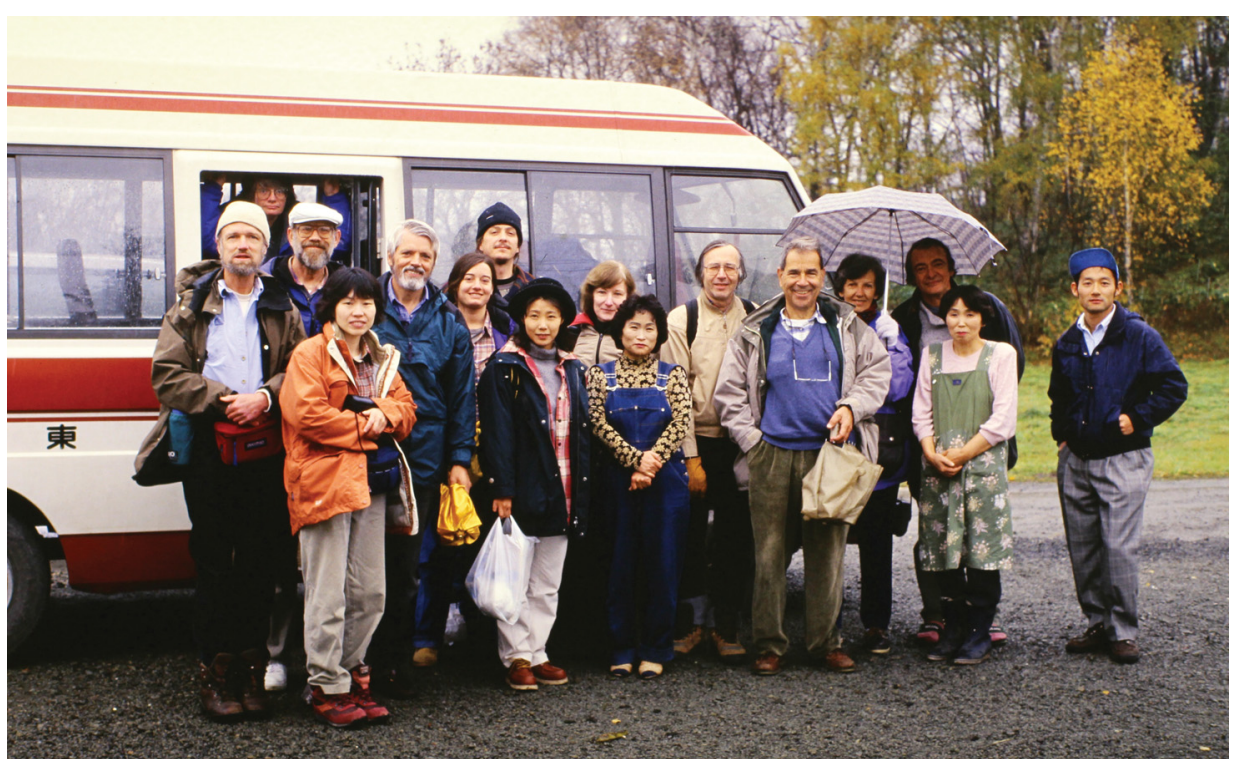

Fig. 4. The group of volunteers (Team II) in the Rokugo base camp, with project leader Zsolt Debreczy ( 5 th from left), and project coordinator Hiromitsu Kisanuki (far right). 
help of local colleagues: first to read location data from labels with Japanese writing, then to help organising short field trips to the natural habitats of several taxa mostly having a range in the middle and southern parts of Japan.

Besides the herbarium work, Kyoto as a location provided excellent opportunities to explore nearby (semi)natural habitats and visit living collections with many native (and some introduced) woody plants. Short documentations of the forest flora including places such as Yoshida hill (Fig. 5/1a), Mt Kurama (Fig. 5/1b), Mt Hiei (Fig. 5/1c) and later (on two occasions) the Ashiu Forest (Fig. 5/1d) provided the initial specimens, photographs, and habitat sketches needed for the Atlas project during this visit. Several trips to the Kyoto Prefectural

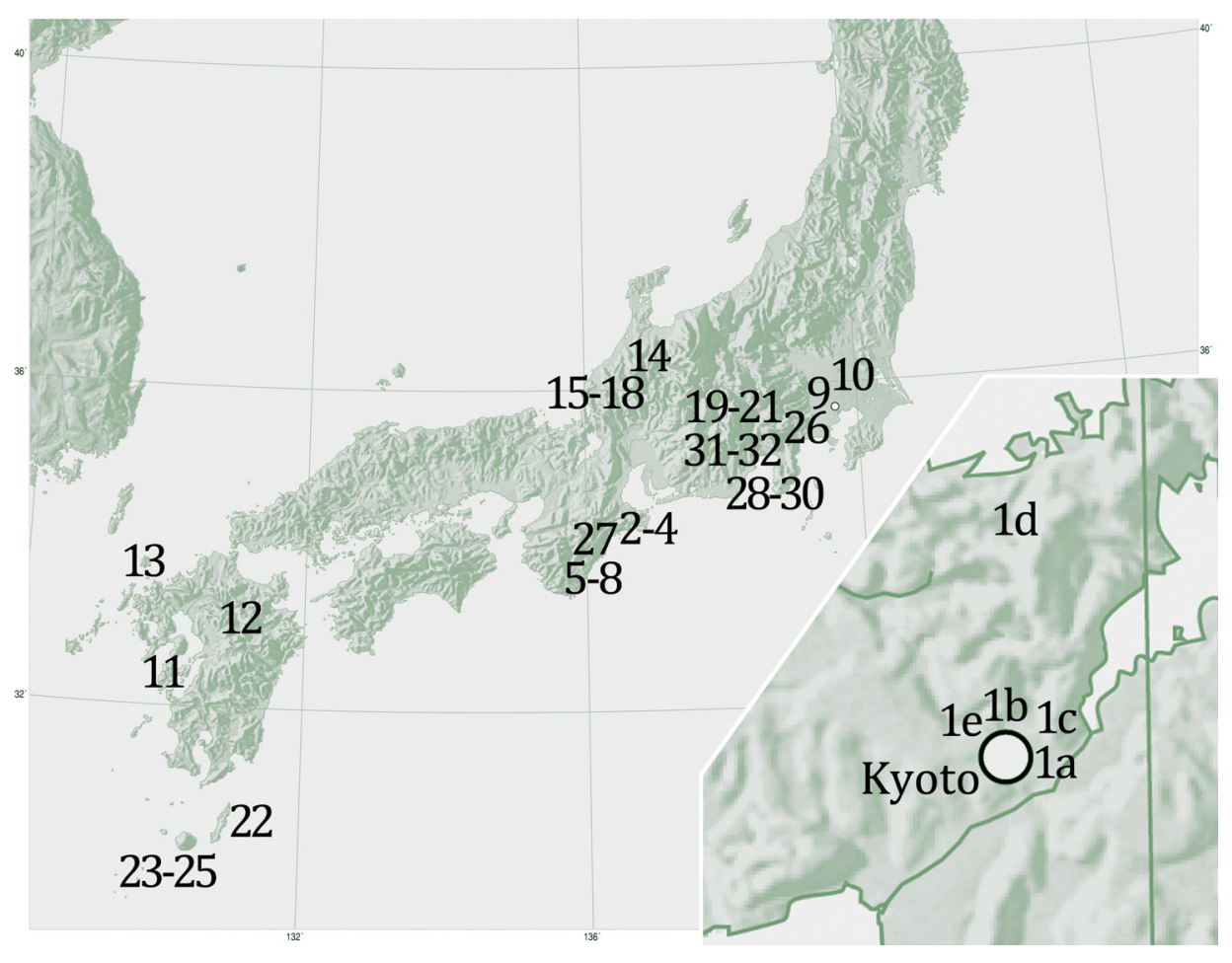

Fig. 5. Map of Japan south of latitude $40^{\circ}$ with the main locations of the second conifer documentation for the Dendrological Atlas Project (June 1-September 30, 2013) (see details in text). Inset: the surroundings of Kyoto magnified. 1 (a-e) - Kyoto and adjacent areas; $2-8$ - the eastern coastal areas of Kii Peninsula; 9 - Tokyo University and the Koishikawa Botanical Garden; 10 - Tsukuba, National Science Museum and Botanical Garden; 11 - Hirado Island; 12 - Mt Kuju; 13 - Iki and Tatsu-no islands; 14 - Haku-san; 15-18 - Coastline and forests in the vicinity of Kanazawa; 19 Yatsuga Mts; 20 - Akaishi range; 21 - Kiso range; 22 - Tanega-shima; 23-25 - Yaku-shima; 26 - Tama Forest Station; 27 - Kii Peninsula, Odaigahara Mts; 28-30 - Izu Peninsula; 31 - Yamanakako (lake); 32 - Mt Fuji. 
Botanical Garden, as well as the Osaka Nagai Botanical Garden, and the Osaka City University Botanical Garden have also resulted in a good number of specimens and visual documentation for the project. Coupled with subsequent visits up to mid-September, at these places a documentation of about 250 woody plant taxa was possible, mainly non-conifers, usually in two stages of their development. Another important location was the Kamigamo Experimental Forest Kyoto (Fig. 5/1e), where on two occasions, a few exotic conifers in their best coning stages could be documented, including Glyptostrobus pensilis, Keteleeria davidiana, and Pinus fenzeliana.

\section{PERIOD OF THE “SHORT EXPEDITIONS”}

These were led to the middle parts of Honshu, and various locations in Kyushu.

$$
\text { July 7-9, first trip to Kii Peninsula }
$$

(Figs 6-8)

This period was planned to locate scattered juniper and podocarp populations and document other trees in the coastline and in the vicinity of the Nachi Falls. Organised by Mr Takayuki Ohgue and Mr Jiro Oda, with other colleagues joining later, we could explore habitats with Juniperus conferta, Nageia nagi, Pinus densiflora, P. thunbergii, Podocarpus macrophyllus and their associated plants. Most important locations were: seaside rock (mainly chert) outcrops at the south tip of Shima Peninsula (Fig. 5/2); a fragment of littoral old-growth vegetation surrounding Kuki Shrine, south of Owase (Fig. 5/3); remnant old-growth forest (with a ca 1,000-year-old Cinnamomum camphora) noted for ancient trees of Podocarpus macrophyllus near Asuka Shrine, south of Owase (Fig. 5/4, and Fig. 6); dwarfed littoral vegetation and adjacent low forest on and near large seaside rocky surfaces in the south part of Tategasaki Peninsula, south of Owase (Fig. 5/5); the oldest tree of Nageia nagi in Japan (Fig. 7), estimated to be at least 800 , or perhaps 1,000 years old, standing in the Hayatama Shrine compound in the coastal town of Shingu (Fig. 5/7); a "floating sphagnetum" (protected as National Natural Monument) at Ukishima, Inosawa, in the greater Shingu city area, with low trees of Cryptomeria (to 10-12 m) and a dense subtropical vegetation (Fig. 5/7); and mixed forests around Nachi Falls (Nachi no Taki, with a 133-meter water drop) in the Kumano region (Fig. 5/8, and Fig. 8).

\section{July $12-18$, first trip to Tokyo and Tsukuba}

The purpose of this trip was to work in three herbaria (two collections at the University of Tokyo, and one at the National Science Museum, Tsukuba). 


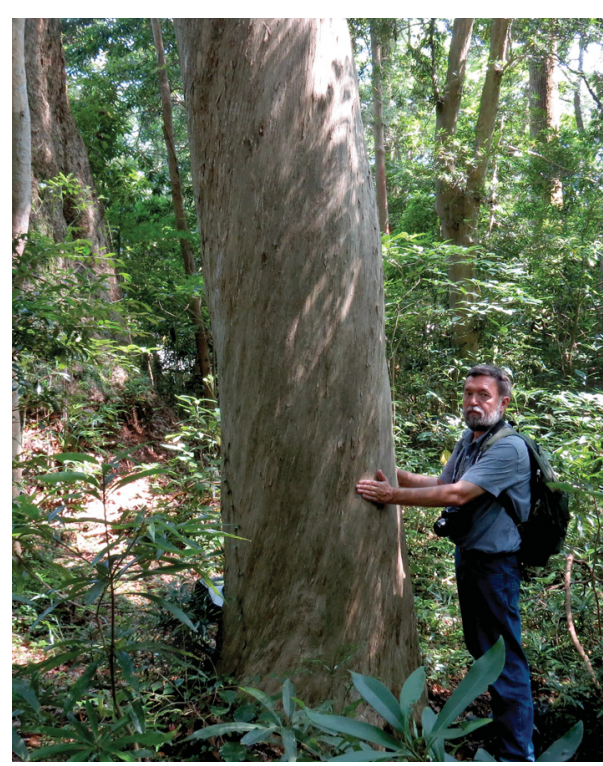

Fig. 6. A very old tree of Podocarpus macrophyllus (girth: $184 \mathrm{~cm}$, height: ca $18 \mathrm{~m}$ ) in a remnant old-growth forest near Owase (eastern Kii Peninsula).

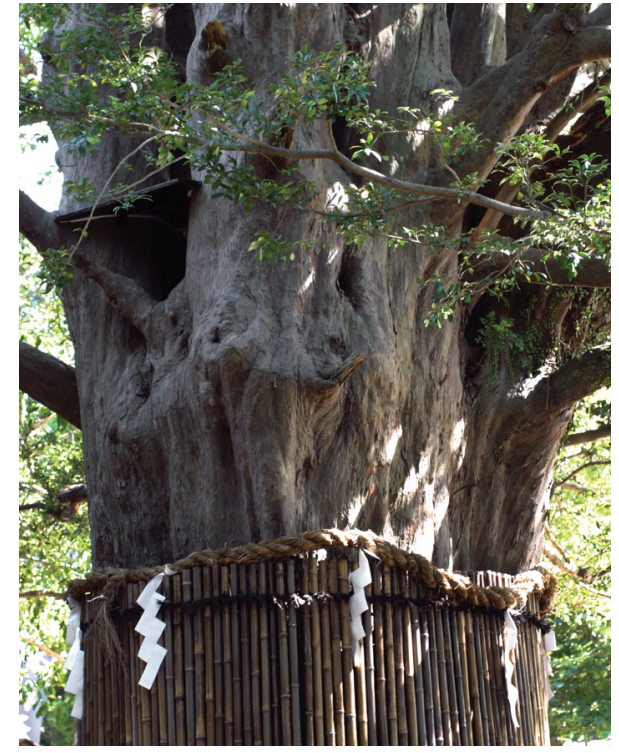

Fig. 7. The oldest known tree of Nageia nagi in Japan (the trunk diam. is given as ca $2 \mathrm{~m}$, with height of $c a 20 \mathrm{~m}$ ), in the Hayatama Shrine compound, Shingu town (eastern Kii Peninsula).

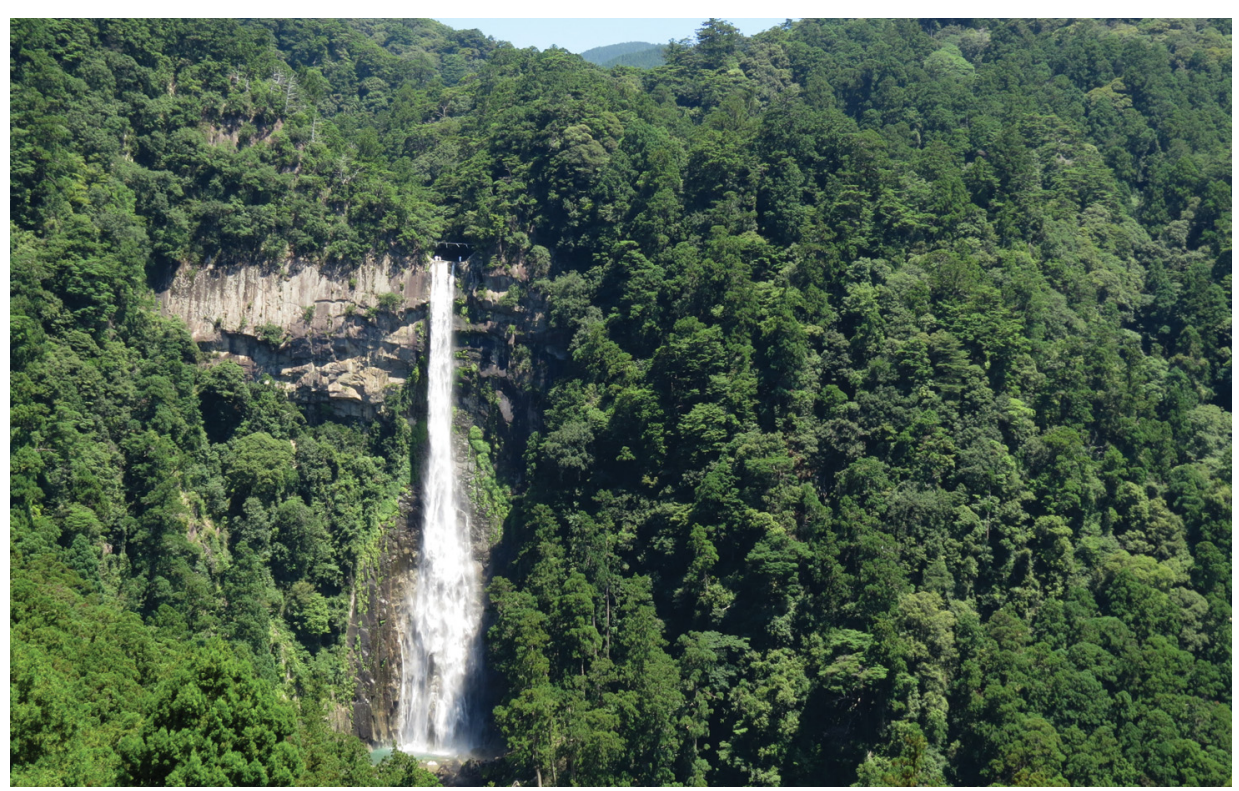

Fig. 8. Nachi Falls in eastern Kii Peninsula, with the surrounding primary evergreen forest (with conifers incl. Abies firma, Chamaecyparis obtusa, Cryptomeria japonica, and Podocarpus macrophyllus). 
In the herbaria, mainly double checking of Juniperus and Pinus samples and occurrences were made. In Tokyo (Fig. 5/9), the herbarium work was assisted by botany professor Jin Murata (who is also director of the Koishikawa Botanical Garden, University of Tokyo); and in Tsukuba (Fig. 5/10), by herbarium curator Dr Atsushi Ebihara. At the Tsukuba Botanical Garden, located at the National Science Museum, additional documentation of mainly Japanese woody plants was made with the assistance of the director, Dr Goro Kokubugata and his coworkers. Here, a few (in part, non-native) conifers important for the Atlas project were also documented, including Agathis australis, Juniperus lutchuensis, J. taxifolia, Pinus densithunbergii, Taxus wallichiana, and Taxus cuspidata var. nana.

$$
\text { August 1-4, trip to Kyushu }
$$

Accompanied by professor Nagamasu, this trip was devoted to search for 4-5 taxa of juniper and a few other gymnosperms. In the first two days the field work was spent in Hirado Island, following up on references to very local juniper occurrences. On the slopes of Mt Kurokami (Fig. 5/11), we could locate three species: Juniperus procumbens, J. rigida, and J. sargentii. On the main island (Kyushu), during a hike to Mt Kuju (main peak: 1,787 m, Fig. 5/12), on higher slopes between 1,500 and 1,700 $\mathrm{m}$ we documented a juniper that requires further taxonomic study. Then we travelled to Iki Island (Japan Sea) and from there to the small islet of Tatsu-no-shima (Fig. 5/13) to explore a classical occurrence of $J$. procumbens a few metres above sea level.

\section{August 18-23: trips to the vicinity of Kanazawa}

(Figs 9-11)

The work in Ishikawa Prefecture was organised by Dr Mariko Nakano of the Ishikawa Museum of Natural History located near Kanazawa City. The first expedition was led to Haku-san (Fig. 5/14), a stratovolcano (2,707 m; with the last eruption in 1659) covered by a rich vegetation including a few conifers, the conservation land spanning the borders of Fukui, Gifu, Ishikawa, and Toyama prefectures. A hike from $c a 1,400$ to $2,400 \mathrm{~m}$ made it possible to document the zonation of the broad-leaved and mixed forests and recording/sampling the plant associations of Abies mariesii (1,800 $\mathrm{m}$ and higher, Figs 9-11), Juniperus communis var. hondoensis (around 2,470 m), and Pinus pumila (2,100 $\mathrm{m}$ and higher). This hike was followed by a seashore trip to Komatsu city (Fig. 5/15) to document a 200-year old stand of Pinus thunbergii, then to Katano beach (Fig. 5/16), and the Kashima and Io-zen Forests (Fig. 5/17-18). Conifers documented in these locations included Cephalotaxus harringtonii, C. h. var. nana, Juniperus conferta, J. rigida, Pinus pumila, P. thunbergii, Podocarpus macrophyllus, and Torreya nucifera var. radicans. 


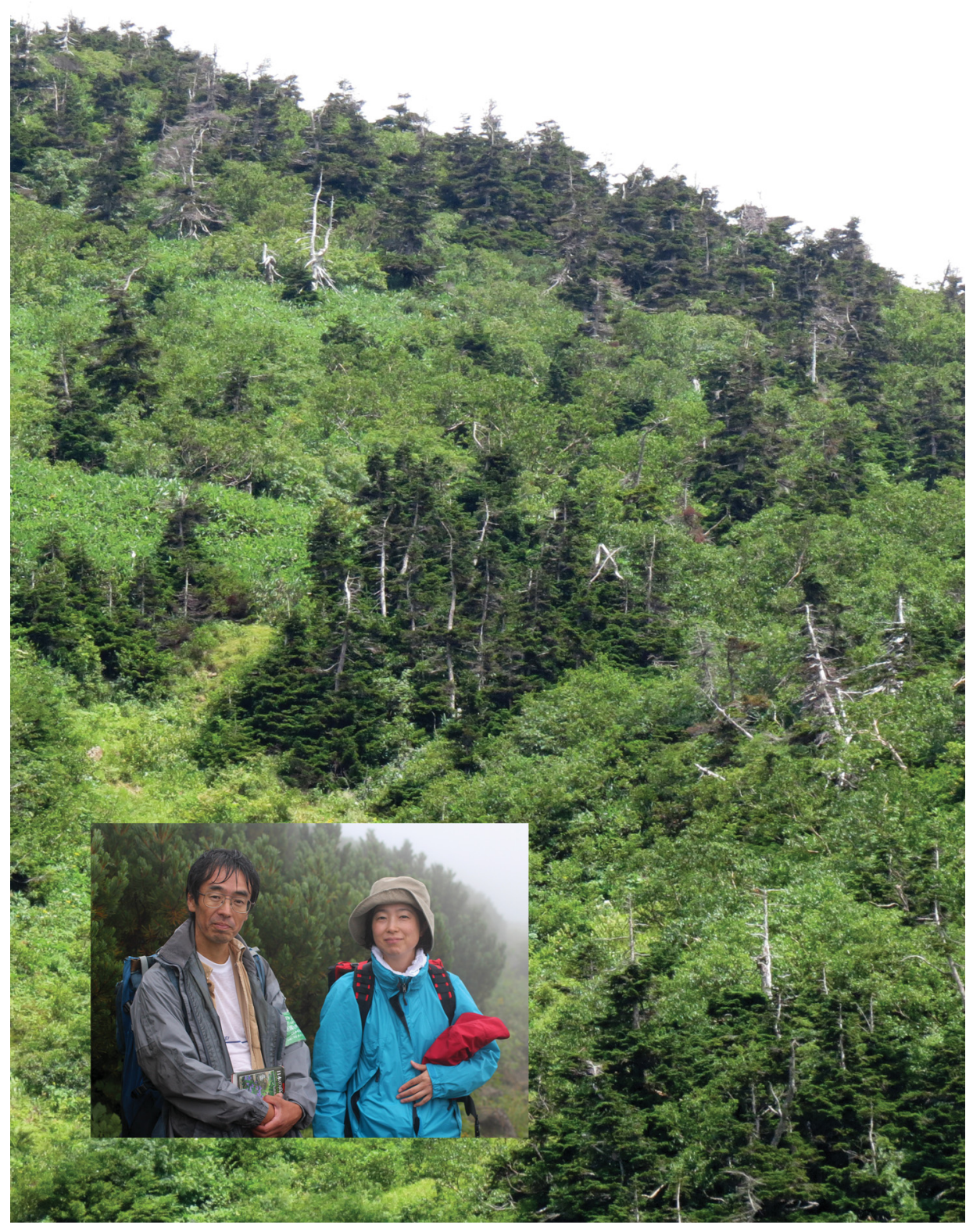

Fig. 9. The higher slopes of Haku-san (2,100-2,200 m), middle Hokkaido, primarily with Abies mariesii in mixed low stands of subalpine vegetation (refer to Fig. 11). Inset: Drs Mariko Nakano (on the right), and Nobukazu Shirai, who guided the tour. 

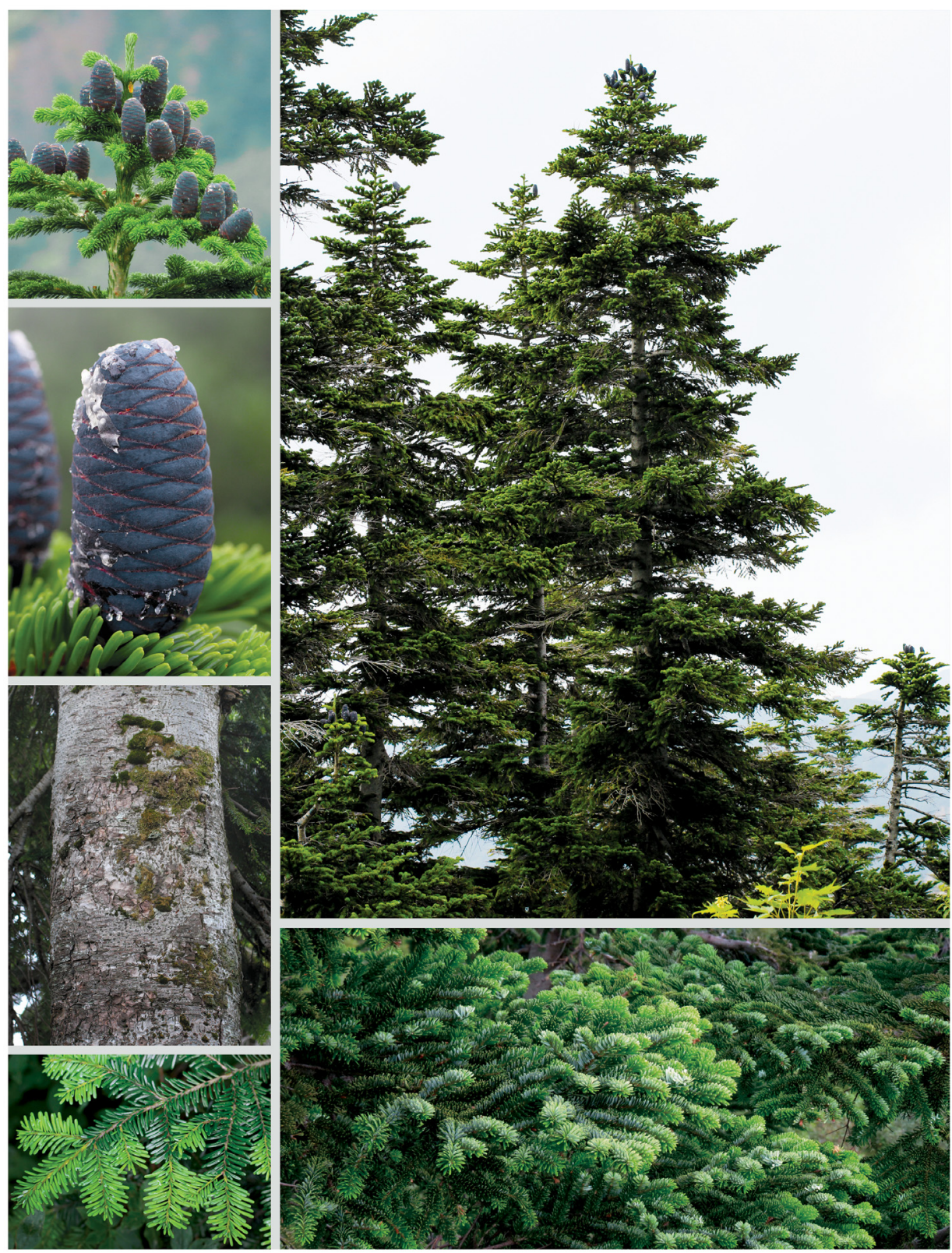

Fig. 10. A photo plate of Abies mariesii prepared for the Dendrological Atlas, based on documentation on Haku-san.

Studia bot. hung. 45, 2014 


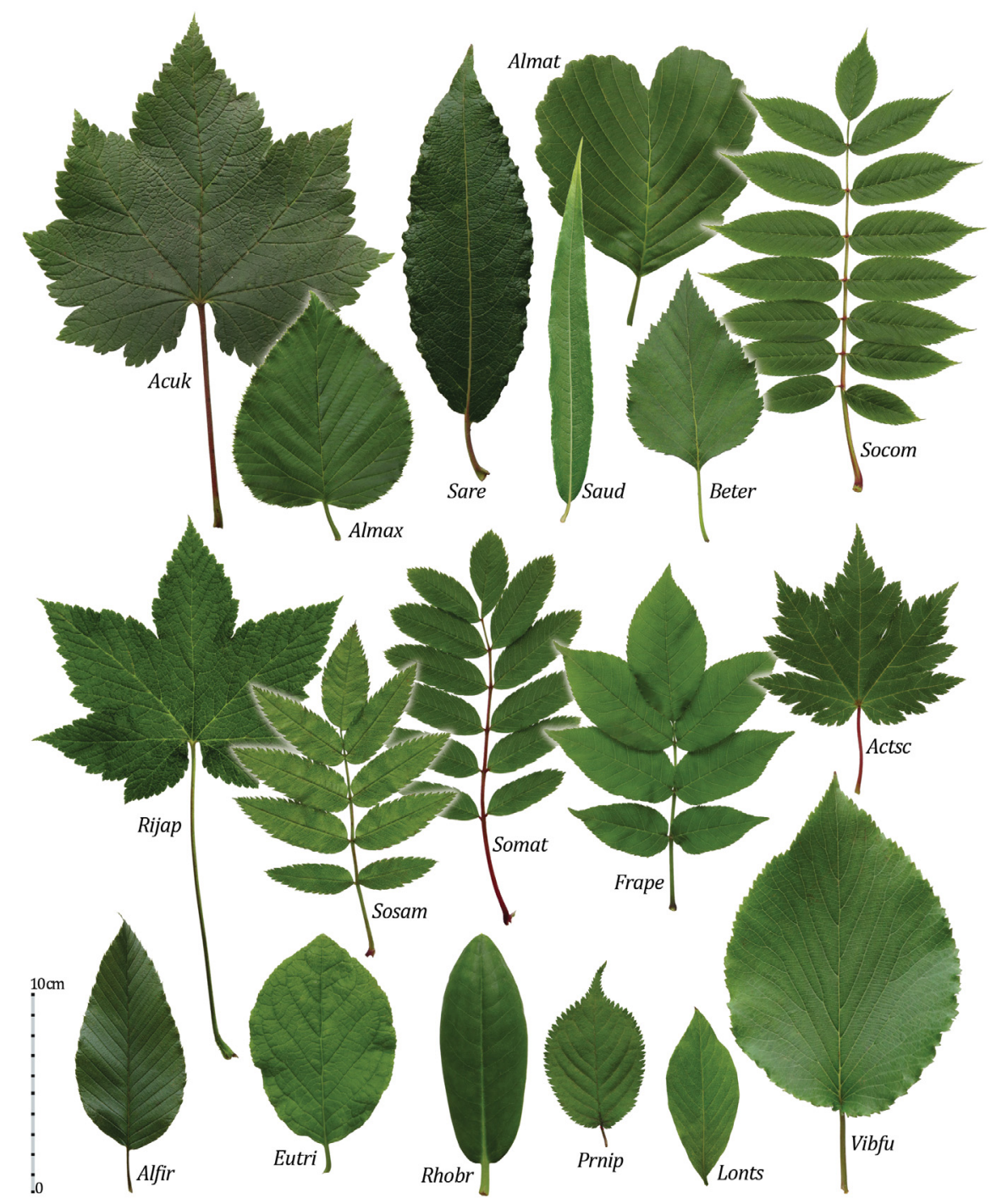

Fig. 11. Leaf photo documentation of woody plants occurring in primary stands of Abies mariesii on Haku-san, at around 2,150 m, 36 $08^{\prime} 29.72^{\prime \prime} \mathrm{N}, 136^{\circ} 45^{\prime} 33.29^{\prime \prime} \mathrm{E}$. In this subalpine habitat the highest trees are Abies $(<10 \mathrm{~m})$, the highest non-conifers in the upper broad-leaved canopy (here designated A2) reach $<8 \mathrm{~m}$, the upper shrub layer $(\mathrm{B} 1)<3 \mathrm{~m}$, the lower shrub layer $(\mathrm{B} 2)<1.5 \mathrm{~m}$. Species in the A2 layer: Acer ukurunduense (Acuk), Alnus maximowiczii (Almax), Salix reinii (Sare), Salix udensis (Saud), Betula ermanii (Beter), Alnus matsumurae (Almat), Sorbus commixta (Socom); B1 layer: Ribes japonicum (Rijap), Sorbus sambucifolia (Sosam), Sorbus matsumurana (Somat), Fraxinus apertisquamifera (Frape), Acer tschonoskii (Actsc); B2 layer: Alnus firma (Alfir), Euonymus tricarpus (Eutri), Rhododendron brachypodum (Rhobr), Prunus nipponica (Prnip), Lonicera tschonoskii (Lonts), Viburnum furcatum (Vibfu). 


\section{August 25-27: trips to the Japanese Alps}

(Figs 12-14)

After thorough preparations these trips were made with the guidance of $\mathrm{Dr}$ Toshio Katsuki from the Forest and Forest Product Research Institute. The purpose of the visits was the documentation of two narrow-endemic conifers of the Japanese flora, and other woody plants in their associations. One day was devoted to travel to Nishidake National Forest (Fig. 5/19), part of the Yatsugatake (range), to explore a hidden and strictly protected stand of Picea koyamae (Fig. 12), and locate a small grove of another endemic, P. maximowiczii (Fig. 13). Additional conifers documented were Abies homolepis, Larix kaempferi, Picea alcoquiana, and Pinus koraiensis. The next trip was led to the Akaishi range (Fig. 5/20), Kurokochi National Forest, home to a few remnant trees of Picea koyamae, and old-growth stands of Abies homolepis, A. veitchii (including its green-coned form), Chamaecyparis pisifera, Larix kaempferi, Picea alcoquiana, Picea jezoensis var. hondoensis, and Tsuga diversifolia (Fig. 14). The third-day trip was made to high ranges of Kiso-Komagatake (Kiso Mts, Fig. 5/21), where excellent subalpine stands of Pinus pumila were documented, with several other conifers at mid-elevation of the mountain.

\section{September 1-2: a brief trip to Tanega-shima}

(Figs 15-16)

Arranged and led by professor Nagamasu, this whirlwind trip focused on the documentation of a Japanese endemic conifer, Pinus amamiana. It was located in 3 nearby sites, including one that is considered the best primary habitat on Tanega-shima (Fig. 5/22). Besides this unique pine, the other gymnosperm species documented was Nageia nagi occurring in association with $P$. amamiana (Fig. 16), and as usual, most associated plants of these species were recorded. Large stands of Juniperus conferta were also documented in the southwestern shores of the island (Fig. 15).

September 6-9: Yaku-shima

(Figs 17-19)

Yaku-shima is the main homeland of ancient stands of Cryptomeria japonica ("Yaku-sugi", Fig. 17), and Pinus amamiana, the latter occurring here in sites and associations different from those on Tanega-shima. This trip was aided by a Kyoto University student, Mr Ryo Sakurai, and accompanied by two visitors from Hungary, Péter Pálfi and Péter Gurisatti. In the first day, ancient trees and forests of Sugi (Cryptomeria japonica) were documented, with fir and hemlock (Abies firma, Tsuga sieboldii) mingled in the old-growth stands. The first day 


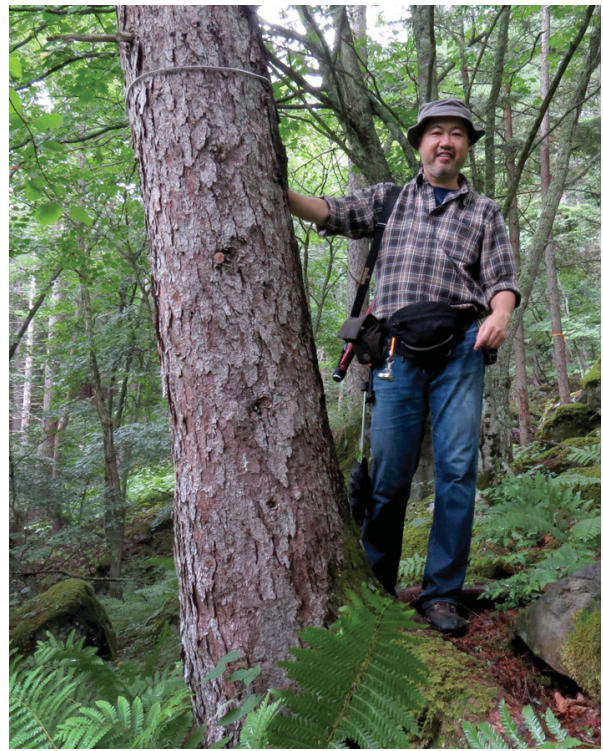

Fig. 12. A mature tree of Picea koyamae (height about $20 \mathrm{~m}$, trunk girth $135 \mathrm{~cm}$ ) in a strictly protected area of the Nishidake National Forest, Yatsugatake Mts, Honshu, at around 1,800 $\mathrm{m}$, with site researcher Toshio Katsuki (Forest and Forest Product Research Institute).

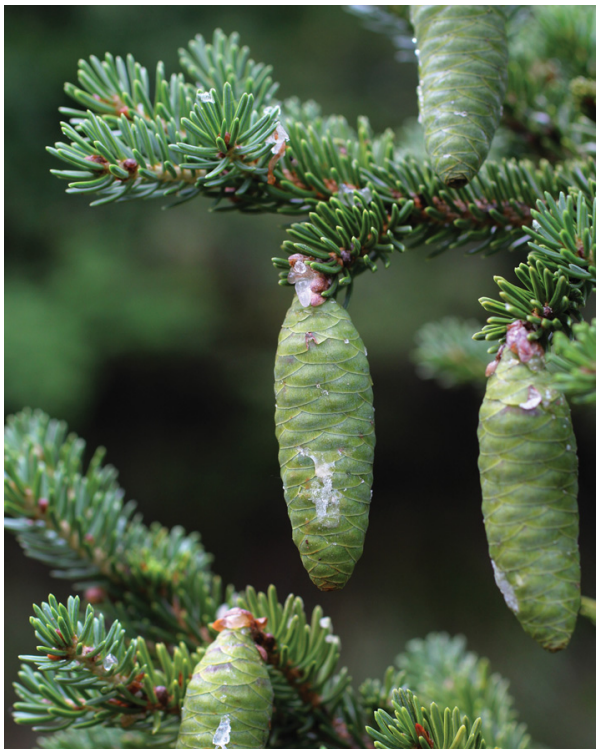

Fig. 13. Coning branch of Picea maximowiczii, another endemic species of middle Honshu; several trees and associated vegetation were documented in the Yatsugatake Mts at around $1,800 \mathrm{~m}$.

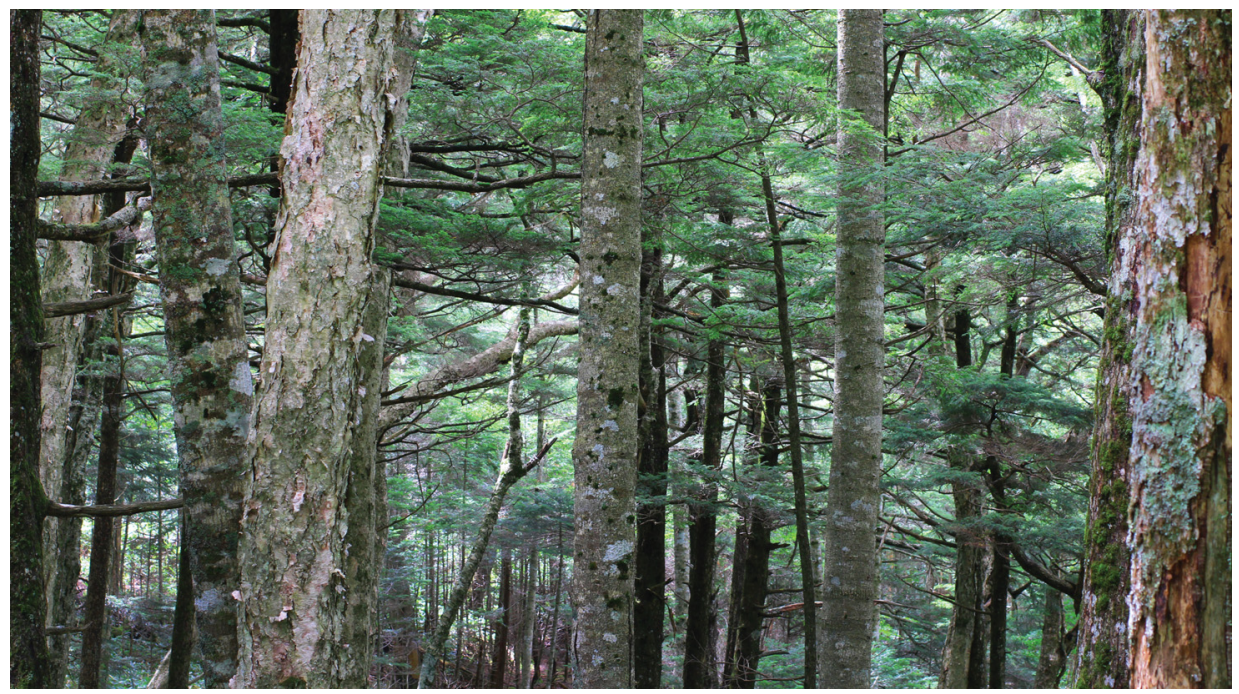

Fig. 14. Old-growth mixed forest of Abies veitchii and Tsuga diversifolia, with Betula ermanii and a few other broad-leaved trees intermixed with these conifers in the Akaishi range, Kurokochi National Forest, at around 1,900 m elevation (middle Honshu). 


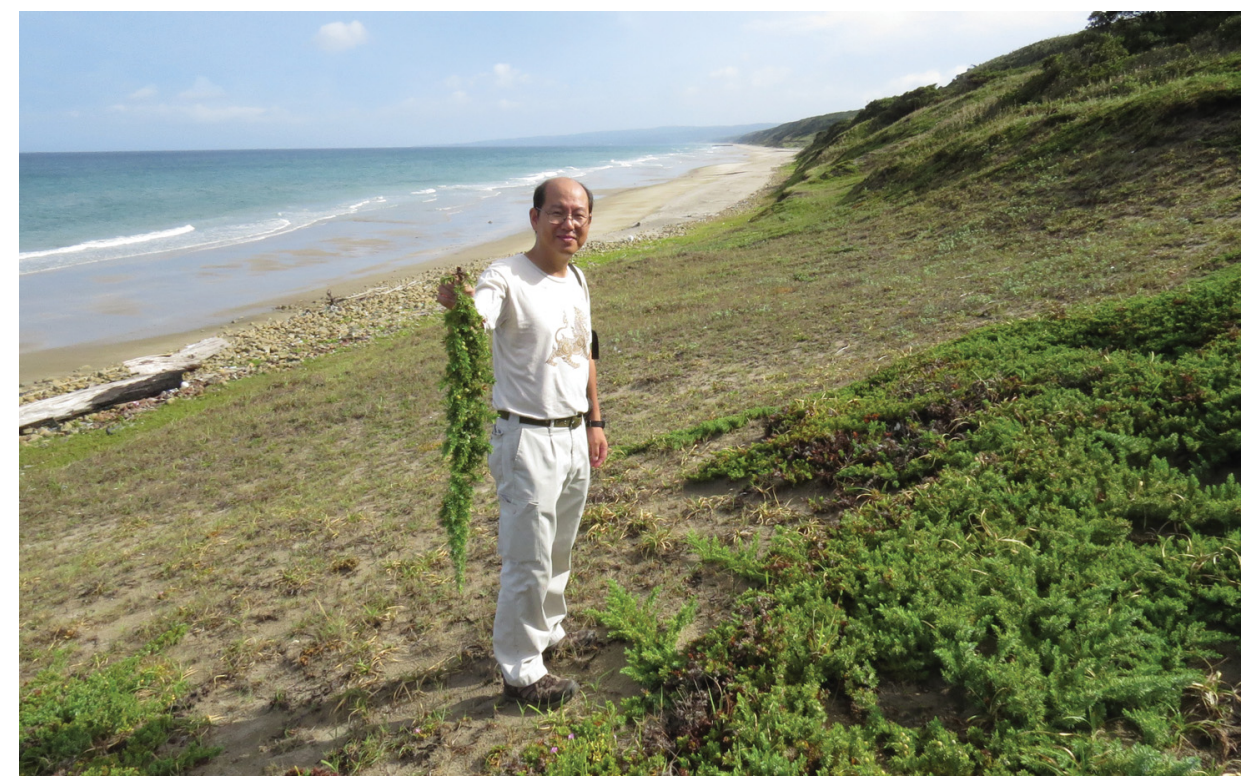

Fig. 15. Botany professor Hidetoshi Nagamasu (KYO) with a branch of Juniperus conferta, while documenting the species and its associated plants in the southwestern shores of Tanega-shima ( $\mathrm{S}$ Kyushu).

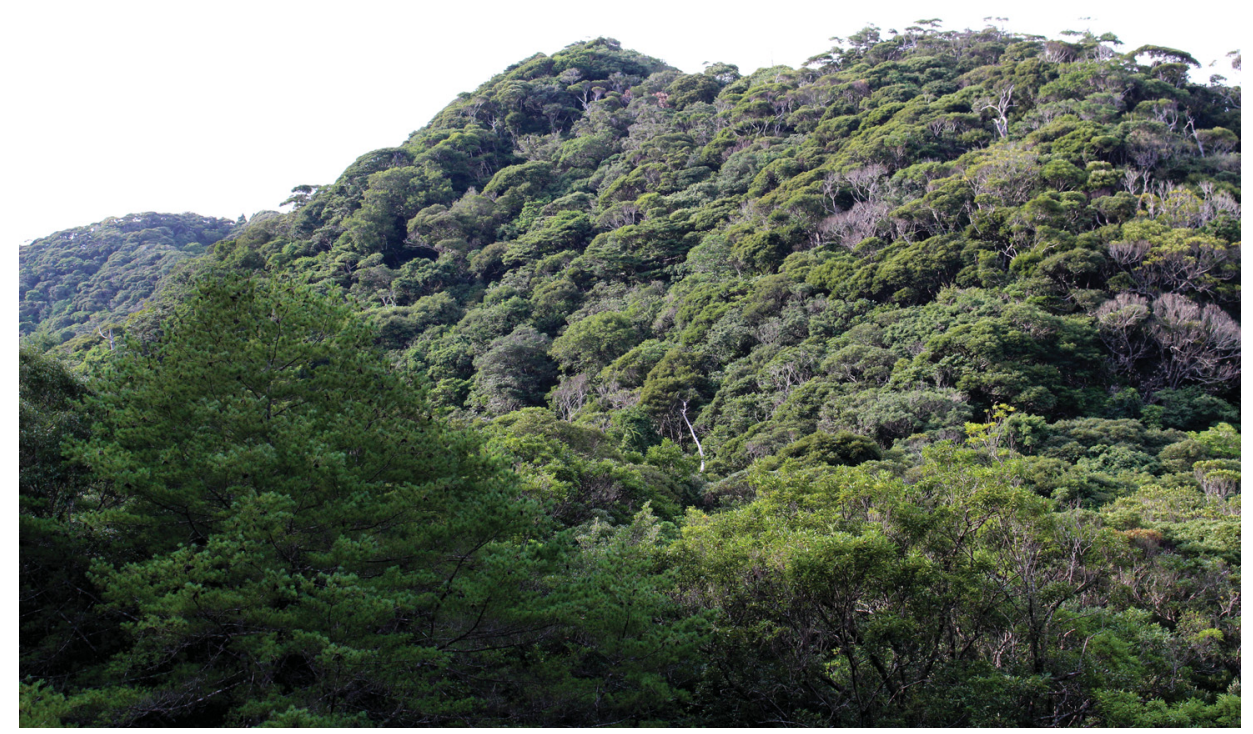

Fig. 16. Untouched habitat of Pinus amamiana (tree on left) at around $100 \mathrm{~m}$ above sea level in a small river valley in north-central Tanega-shima, with primary evergreen subtropical forest covering the adjacent hillsides. 


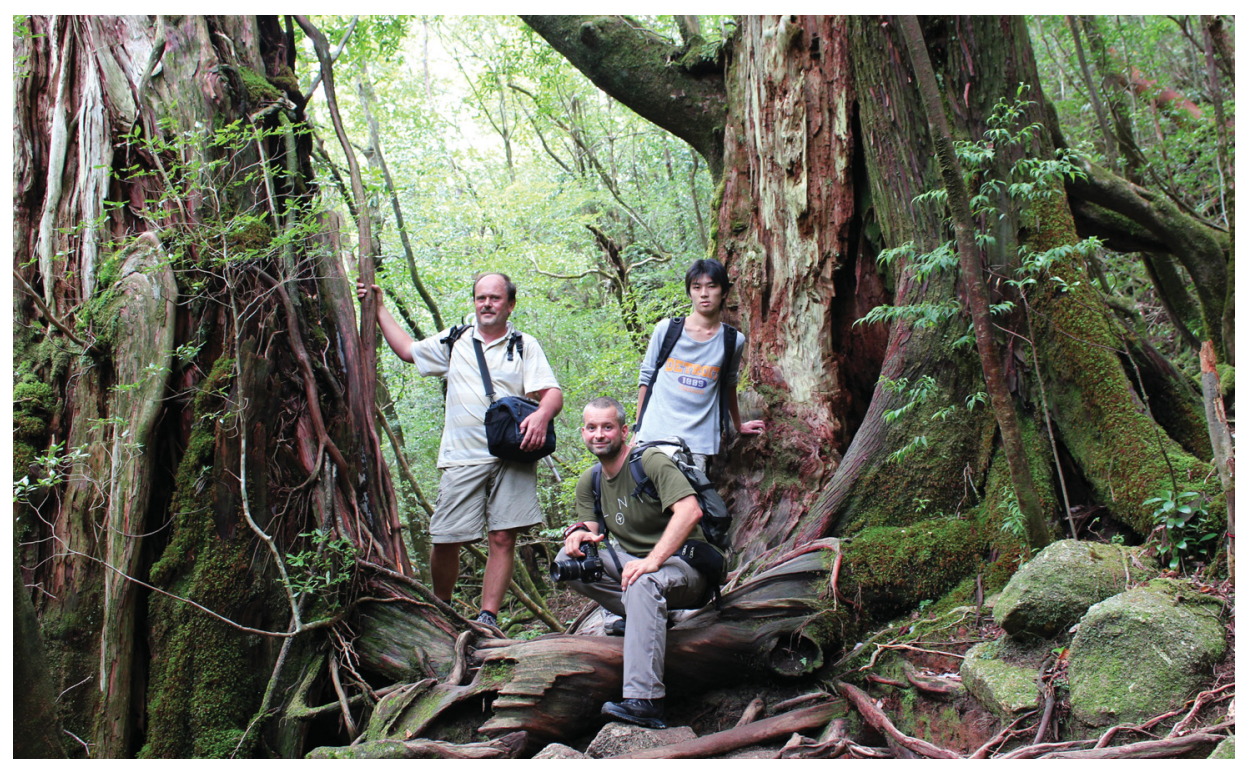

Fig. 17. On way to Jomon Sugi: the trail leads through ancient stands of Cryptomeria japonica, mixed with sporadical trees of Chamaecyparis obtusa, Stewartia monadelpha, Tsuga sieboldii, etc., here at around 1,300 $\mathrm{m}$ (left to right: Péter Pálfi and Péter Gurisatti, joining on the Yaku-shima expedition from Hungary, and Ryo Sakurai, guide from Kyoto University).

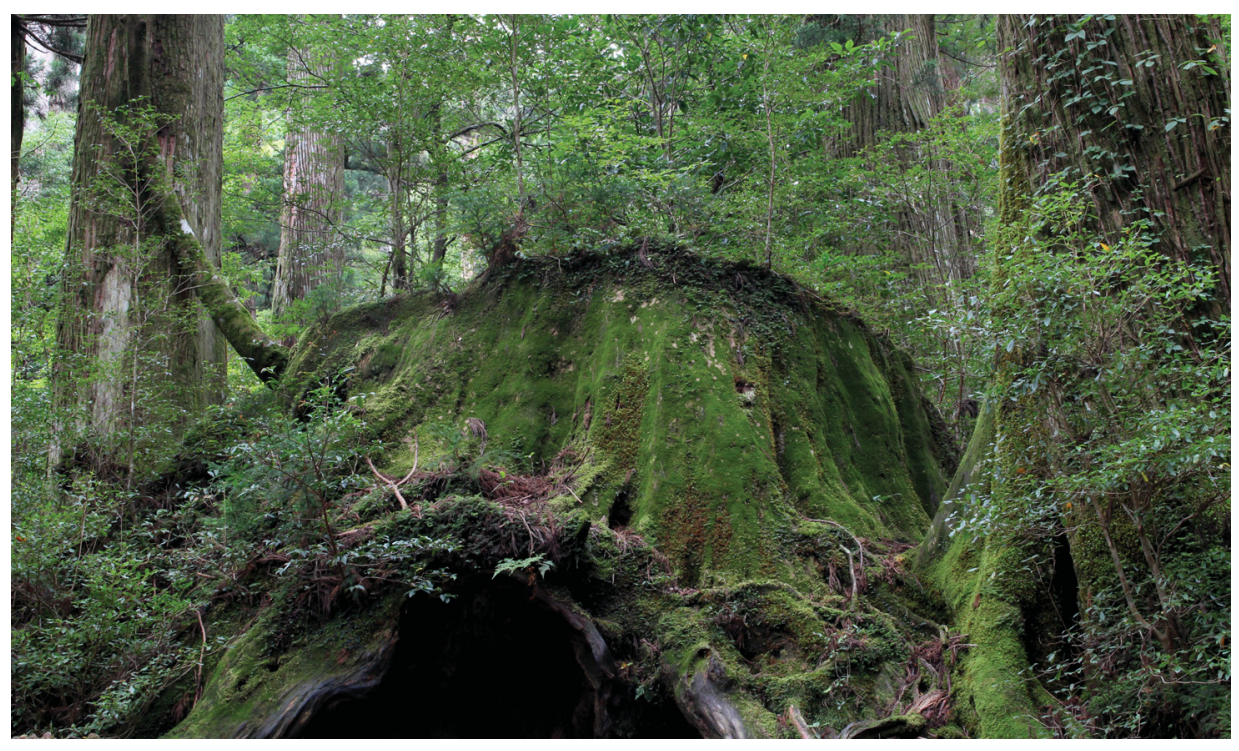

Fig. 18. Remnant of a once very large Cryptomeria, the Wilson Stump (see text), a popular stopping place along the $10+\mathrm{km}$ long trail leading to Jomon Sugi, a very old living Cryptomeria in the central part of Yaku-shima. 


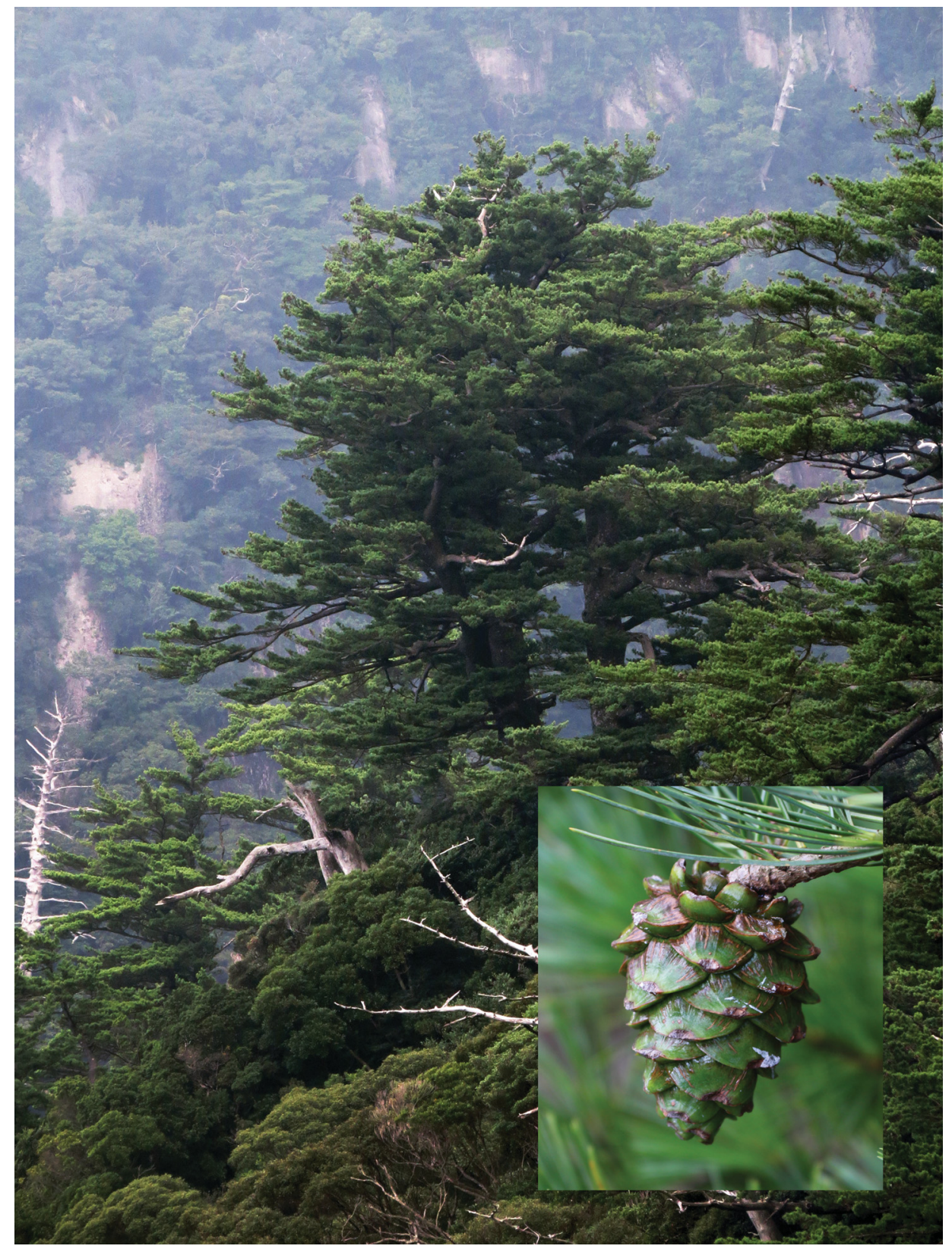

Fig. 19. Pinus amamiana occurs in three stands on Yaku-shima. In the western part of the island it grows on hardly accessible scattered populations on ridges and steep slopes of Mt Kuniwari (1,323 $\mathrm{m})$; this tree is located at around $400 \mathrm{~m}$ elevation. 
hike was made to see Jomon Sugi (Fig. 5/23), a very old living Cryptomeria, and "Wilson Stump" (Fig. 18), a very old stump of an ancient Cryptomeria probably cut in 1586 and named after the famous Anglo-American plant explorer Ernest H. Wilson (1876-1930) who located it in 1914. The second day was devoted to study the juniper of Yaku-shima (in our taxonomy: J. tsukusiensis, see DebReCZY and RÁcz 2011) at the Hananoego site (Fig. 5/24) at around 1,650 m. Finally, we climbed the lower and mid-elevation slopes of Mt Kuniwari $(1,323 \mathrm{~m})$ above the Kawahara coast line, and documented the locally named "Segire" population of Pinus amamiana in its best primary habitat (Fig. 5/25, Fig. 19).

September 16-19: second trip to Tokyo and Tsukuba

This trip included a 2-day stop at the Tama Forest station (Forest and Forest Products Research Institute, Fig. 5/26). Here, Dr T. Katsuki introduced a remnant old-growth forest in which Abies firma is among the dominant upper canopy species. There was also a good opportunity to document many native and some introduced woody plants in the forestry arboretum. A second visit to the Tsukuba Botanical Garden (followed by a stopover at the Koishikawa Botanical Garden) provided another opportunity to document many native trees and shrubs in their fruiting stages.

\section{September 21-23: Kii Peninsula, Odaigahara Mts}

(Figs 20-21)

This brief expedition was made in cooperation with an international team of Scottish, British, and Japanese researchers (led by Peter Baxter, Benmore Arboretum, Royal Botanic Garden Edinburgh; with other colleagues from Edinburgh and the Kew Gardens, and with a Japanese team of experts from 3 institutes, organised by Dr Hiroshi Ikeda and Dr Shinji Fujii), whom I was able to join for the Odaigahara expedition (Fig. 5/27). In this famous place, one of the wettest parts of Japan, the plan was to visit protected sites of several endemic Japanese conifers including Koyamaki (Sciadopitys verticillata) and Toga-sawara (Pseudotsuga japonica). On the first day we went on to the Shionoha location to explore one of the rare Japanese Douglas-fir (Pseudotsuga japonica) habitats. The second day we were led to the Shiokara valley and the surrounding slopes and crests to document several conifer species growing in beautiful scenery. The third day was devoted to the conserved old-growth Pseudotsuga forest of the Myojin valley. Species documented on these days included (besides the two above mentioned conifers) Abies homolepis, Chamaecyparis obtusa, Cryptomeria japonica, Picea jezoensis var. hondoensis, P. torano, Pinus parviflora, Taxus cuspidata, Tsuga sieboldii, and their associated plants. 


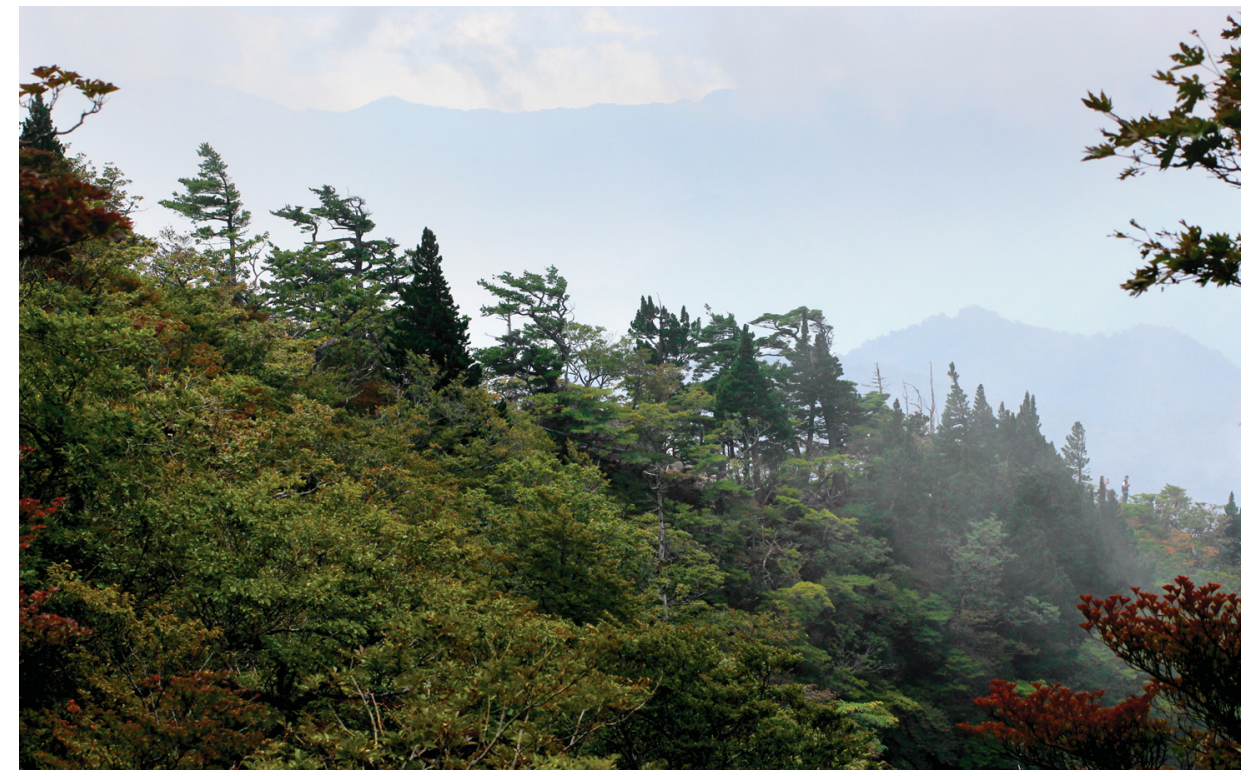

Fig. 20. The Odaigahara Mts in the Kii Peninsula are noted for their wet climate and rugged terrain supporting a rich flora and vegetation, with endemic conifers including Abies homolepis, Picea torano, and Sciadopitys verticillata.

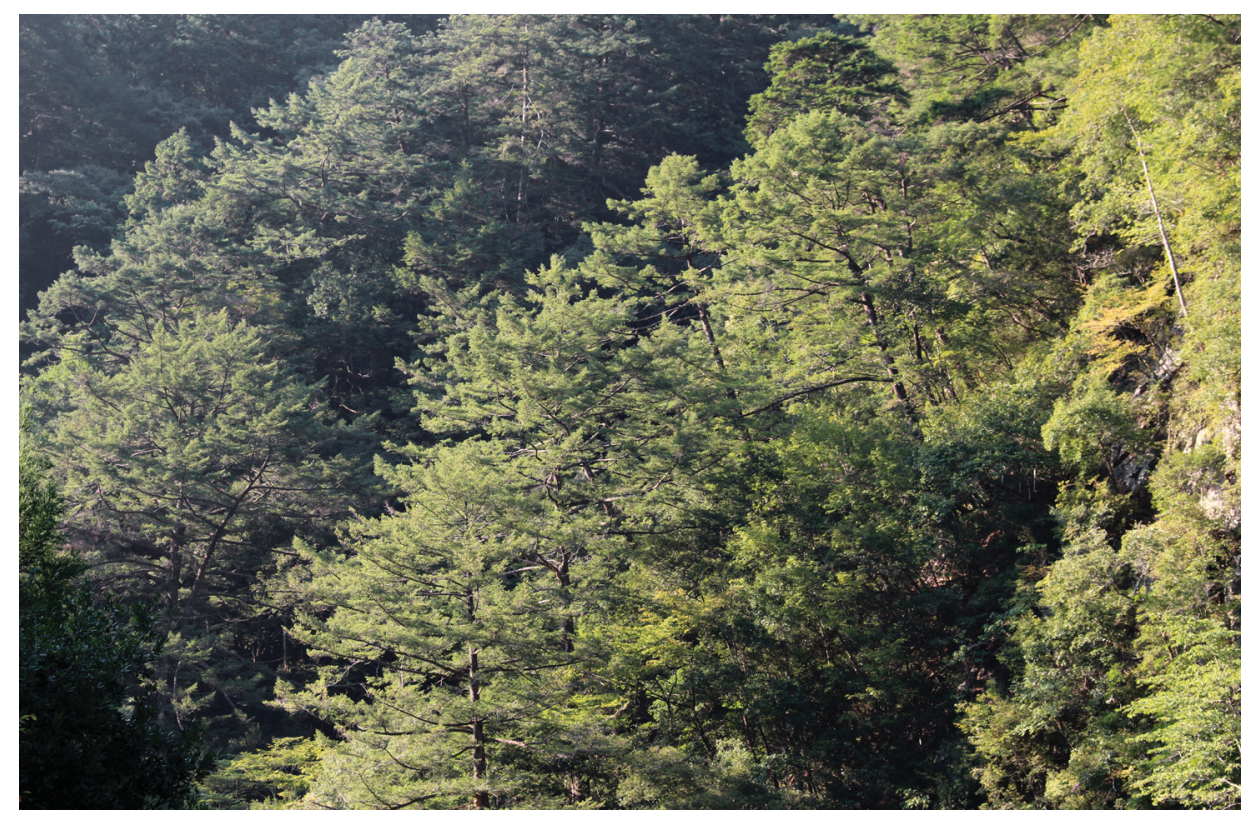

Fig. 21. Primary mixed forest in the Odaigahara Mts with the dominant Pseudotsuga japonica, in a protected area assigned to conserve the untouched habitat of this endemic conifer. 


\section{September 25-27: Izu Peninsula and Mt Fuji}

(Fig. 22)

The last field trip was organised by Dr Shota Sakaguchi of Tokyo University. The goal was to do research on juniper occurrences and document 3-4 other taxa of conifers. On the northwestern tip of Izu, in the mini-peninsula called Osezaki (Fig. 5/28), we documented several ancient junipers (Juniperus chinensis L. s. 1., Fig. 22) and their accompanying vegetation (including Pinus thunbergii and Podocarpus macrophyllus) and found similar habitats further south on the western coast of Izu. The next day we went to the central mountains of the peninsula (Fig. 5/29) to observe vegetation with native Abies firma and Tsuga sieboldii, then the juniper stands of the eastern coastline near Ito city (also Juniperus chinensis s. 1. with a few small plants of J. conferta) (Fig. 5/30). The third day was spent documenting conifers on the foothills and higher slopes of Fujisan, including the famous old-growth forest of Picea torano (with Pinus densiflora) near Yamanakako (lake) (Fig. 5/31). Other woody plants documented primarily at higher elevations (Fig. 5/32) were Abies mariesii, A. veitchii, Larix kaempferi, Picea alcoquiana var. reflexa, P. torano, Pinus parviflora, Tsuga diversifolia, and their associated plants.

\section{OTHER ACTIVITIES}

Four presentations were made to introduce the Dendrological Atlas project, the herbarium of the Hungarian Natural History Museum, the recent publication Conifers Around the World (DEBRECZY and RÁcz 2011) and share results of previous research activities of our team. These presentations were made at Kyoto University (June 16, July 2), Ishikawa Museum of Natural History (August 21), and the Forest and Forest Products Research Institute (September 17).

\section{RESULTS}

35 taxa of Japanese conifers were documented and habitat information gathered (Appendix; Figs 23-26), focusing on the conifers' morphology, variability, associated vegetation, and additional observations related to the species' natural history, conservation status, and cultural contexts. 12 taxa were completely new for the project and for the rest, missing or new materials/documentation were secured. Out of $c a 400$ studied samples in the herbarium of the Kyoto University Museum (KYO) 59 specimens of gymnosperms were annotated. With Dendrological Atlas Project collecting numbers 77101 to 79046 (1,945 entries), including duplicates, about 3,500 herbarium specimens were collected in the field and in living collections. The specimens were dried and organised in the 


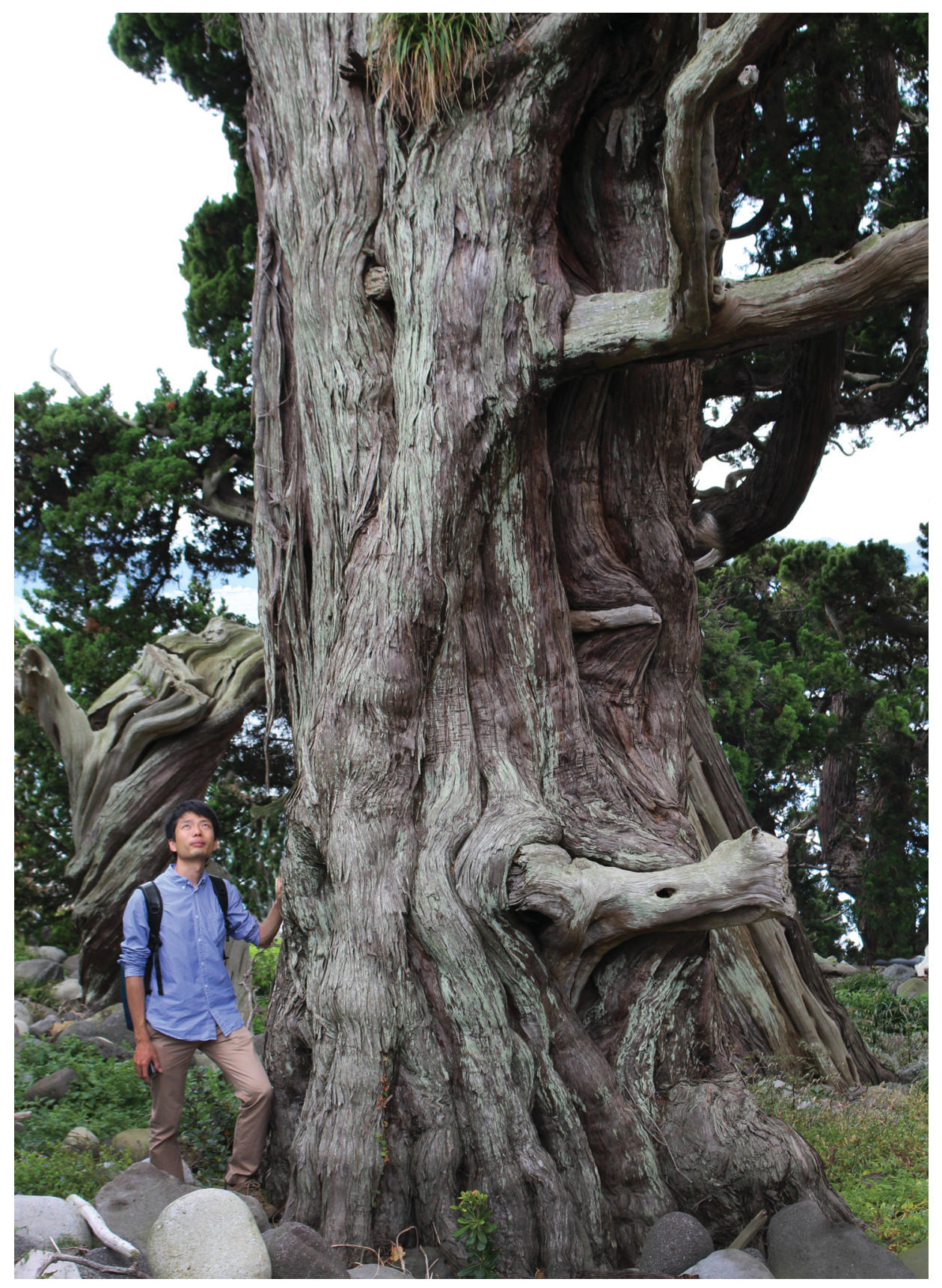

Fig. 22. One of several ancient junipers (Juniperus chinensis sensu lato, with Tokyo University researcher Shota Sakaguchi) at Osezaki, northwestern Izu Peninsula. 


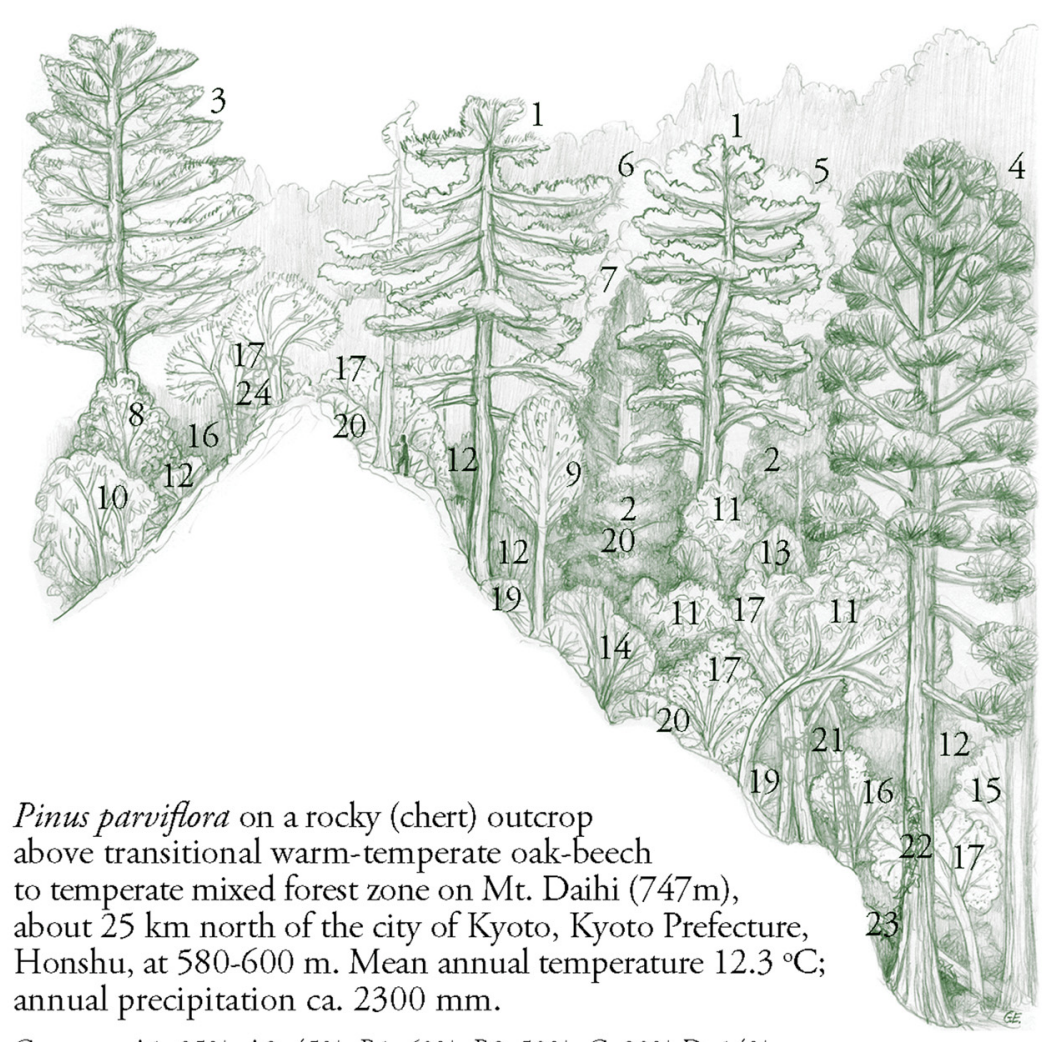

Coverage: A1: 85\%,A2: 45\%, B1: 60\%, B2: 50\%, C: 20\% D: 14\%.

Associated species (AD value in \%): A1 layer: (1) Pinus parviflora (25\%), (2) Chamaecyparis obtusa (15\%), (3) Abies firma (5\%), (4) Cryptomeria japonica (5\%); (5) Quercus salicina (15\% p.12, fig. 465), (6) Qu. sessilifolia (10\% - p.12, fig. 466), (7) Qu. serrata (10\% - p.12, fig. 467), A2 layer: (8) Acer crataegifolium (5\% - p.12, fig. 468), (9) Cornus controversa (5\% - p.12, fig. 469), (10) Clethra barbinervis (15\% - p.12, fig. 470), (11) Gamblea innovans (20\% p.12, fig. 471), (12) Ilex pedunculosa (30\% - p.12, fig. 472), (13) Camellia japonica (5\% - p.19, fig. 621), (14) Rhamnus crenata (20\% - p.12, fig. 473), (15) Styrax japonica (10\% - p.12, fig. 474); B1 layer: (14) Rhamnus crenata (20\% - p.12, fig. 472), (16) Pierisjaponica (30\% p.12, fig. 475), (17) Lyonia ovalifolia (20\% - p.12, fig. 476), (18) Vaccinium oldhamii (15\% - p.12, fig. 477), (19) Rhododendron keiskei (5\% - p.12, fig. 478), B2 layer: (12) Ilex pedunculosa (15\% - p.12, fig. 470), (20) Vaccinium hirtum (5\% - p.12, fig. 479); vines (abundant): (21) Akebia quinata - p.12, fig. 480, (22) Parthenocissus tricuspidata - p.12, fig. 481; (23) Smilax china p.12, fig. 482; C layer: [woody components]: (21) Akebia quinata, (22) Parthenocissus tricuspidata, (24) Ampelopsis brevipedunculata (p.12, fig. 480-483).S

Fig. 23. Habitat profile of a native stand of Pinus parviflora and its major associated plants (prepared for the treatment of this pine species in the Dendrological Atlas), based on sketches, photographs, specimens obtained in the Mt Daihi area, north of Kyoto (artist: Emese Gábor). 

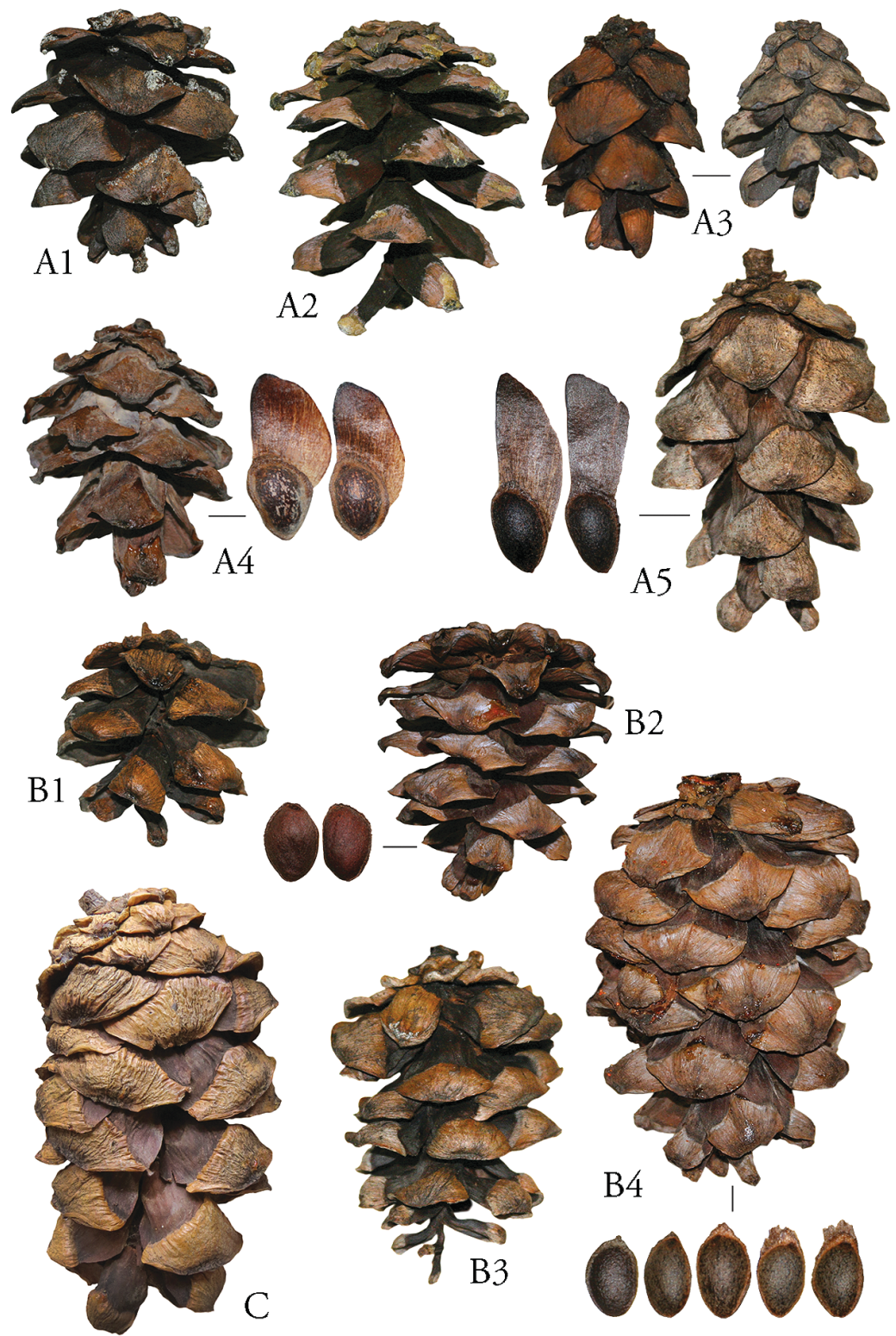

Fig. 24. Cones and seeds of Pinus parviflora, based on documenting specimens in three Japanese herbaria (KYO, TI, TNS). All cones 2/3; all seeds actual size. A: var. pentaphylla (A1: Honshu, Miyagi Pref., Izumi-mura, without elev.; A2: Hokkaido, Furano area, pl. cult. at 100-200 m; A3: Honshu, Jowada, with no additional details; A4: Hokkaido, Mt Apoi, without elev.; A5: Honshu, Nagano Pref., Kakizore, 670 m); B: var. parviflora (B1: Honshu, Yamanashi Pref., Fuji-san, 1,100 m; B2: same but 2,200 m; B3: Shikoku, Ehime Pref., Tsuchigoya, Omogo-Mura, 1,600 m; B4: Shikoku, Ehime Pref.,

Hijashi-akaichi-yama, without elev.); C: Korea (Ullung Do, Kyongsang-Pukto, without elev.). 


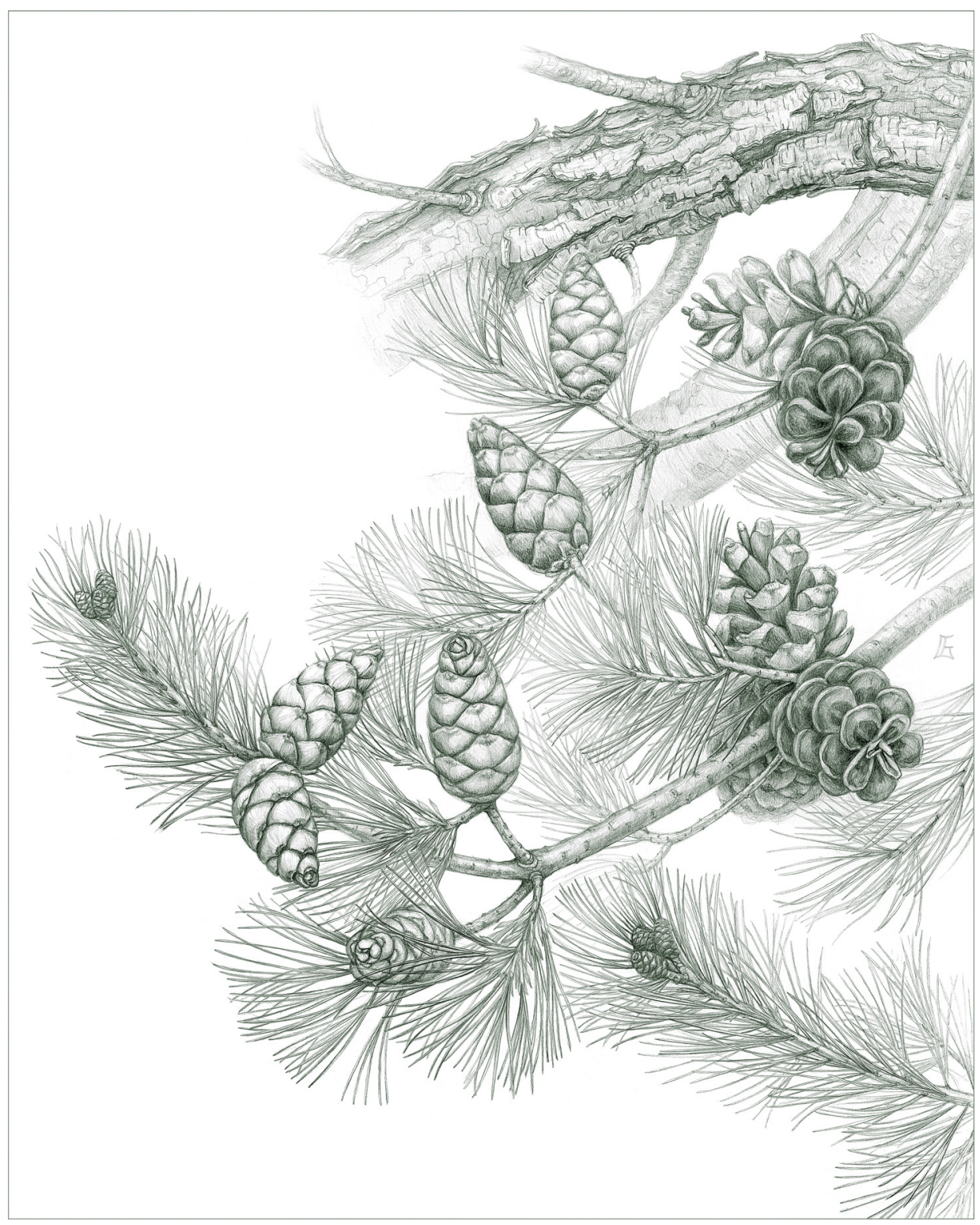

Fig. 25. A full-page illustration of Pinus parviflora created for the Dendrological Atlas, based on specimens from Mt Daihi (refer to Fig. 23). Such hand-drawn illustrations are made for all major species of temperate conifers; first, the botanical sketches (compositions) are prepared by Zsolt Debreczy, and the final illustrations are worked out by artists of the Atlas Project team (here, Emese Gábor). 

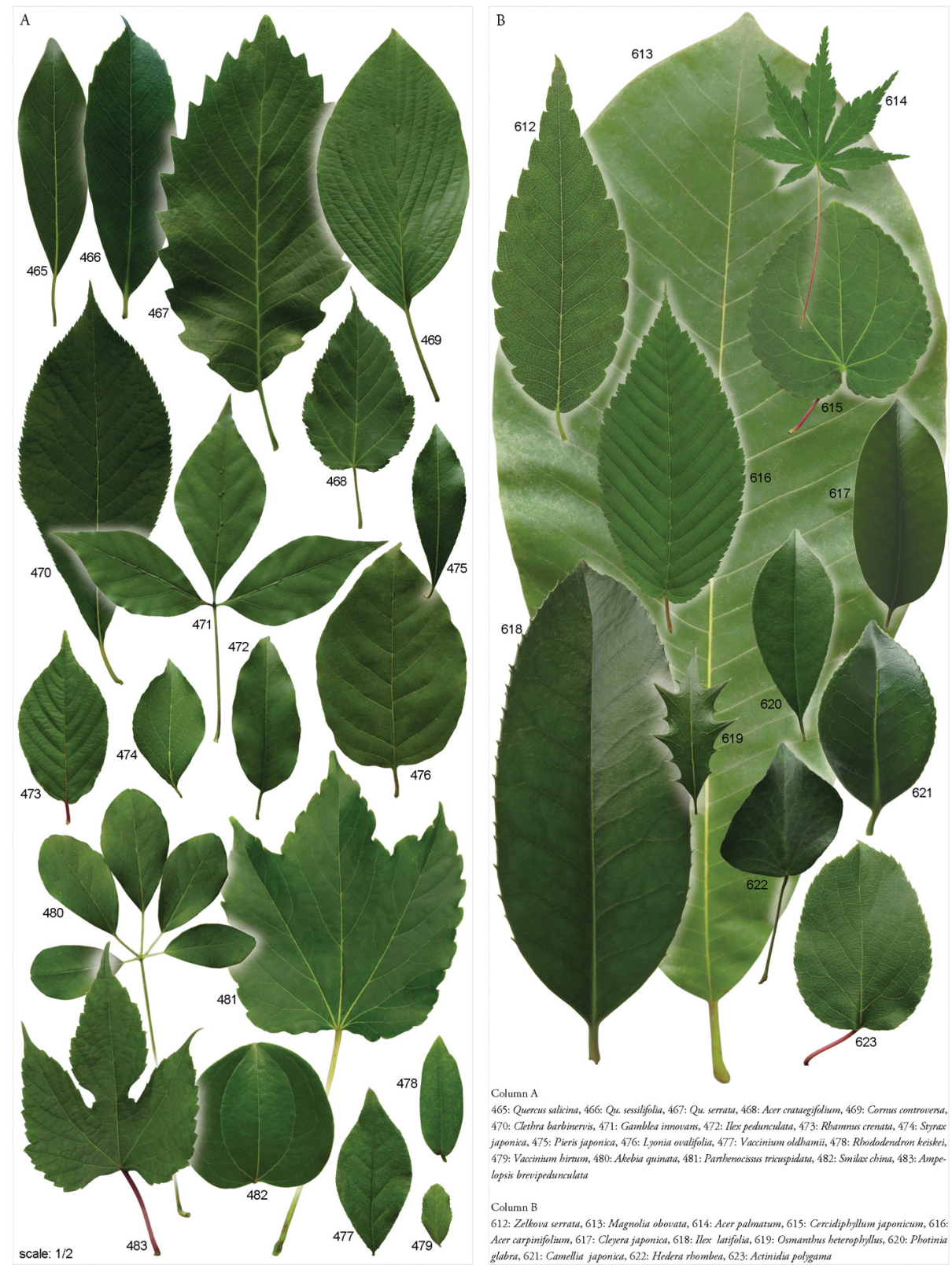

Fig. 26. An Appendix page prepared for the Dendrological Atlas. The left column contains leaf photos of woody plants occurring in the habitat illustrated in Figure 23. Leaf photo numerals correspond to the figure numbers in Figure 23.

Studia bot. hung. 45, 2014 
Kyoto University's facilities and subsequently shipped to BP. Sharing the labelled specimens between the herbaria of the host institute and the Hungarian Natural History Museum is in progress.

\begin{abstract}
Acknowledgements - On behalf of the Dendrological Atlas Project team, our gratitude is expressed to the Kyoto University for supporting this research period. Special thanks are due to Dr Terufumi Ohno, Director of the Kyoto University Museum, Dr Hidetoshi Nagamasu (KYO Curator and botany professor) and his colleague Mr Takayuki Ohgue, as well as to the Kyoto University Museum staff for their kind help in all matters of this research period. For their guidance and assistance in the field trips and in various herbarium and living collections, Mr Yoshihiro Matsuura, Mr Junichi Nagasawa, Mr Hiroyuki Nikuto, Mr Satoshi Koi, Mr Jiro Oda, Dr Atsushi Ebihara, Dr Goro Kokubugata, Prof. Dr Jin Murata, Dr Mariko Nakano, Mr Nobukazu Shirai, Mr Kinoshita Ei'ichiro, Mr Hiroshi Furuike, Dr Toshio Katsuki, Mr Ryo Sakurai, Dr Hiroshi Ikeda, Dr Shinji Fujii, Mr Shuhei Matsuyama, Mr Unno Yamato, Dr Shota Sakaguchi, and their colleagues are thanked.
\end{abstract}

\title{
REFERENCES
}

Debreczy, Zs. and RÁcz, I. (2000): Fenyők a Föld körül. - Dendrológiai Alapítvány, Budapest. $552 \mathrm{pp}$.

Debreczy, Zs. and RÁcz, I. (2011): Conifers around the World. Vol. 1. - Dendropress Ltd., Budapest, pp. 450-503.

Earthwatch, Center for Field Research (1997): Encyclopedia Botanica (Dendrological Atlas). Earthcorps Briefing, Watertown, Massachusetts, 31 pp.

Rehder, A. (1934): Manual of cultivated trees and shrubs hardy in North America. - Macmillan, New York, 930 pp.

\section{Appendix}

The conifer taxa of Japan and the completion status of their documentation for the Dendrological Atlas are listed below. ("Completion" here is restricted to work performed during the two above discussed expeditions to Japan; additional documentations were done in other areas, i.e., cultivation in temperate zones.)

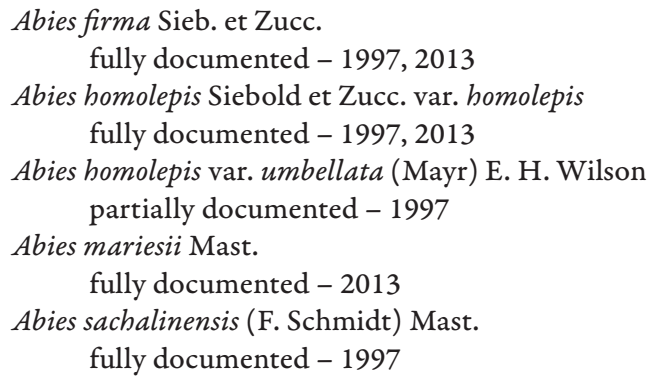


Abies veitchii Lindl. partially documented - 1997; fully documented - 2013

Cephalotaxus harringtonii (Knight ex J. Forbes) K. Koch var. harringtonii fully documented - 1997, 2013

Cephalotaxus harringtonii var. nana (Nakai) Rehder fully documented - 1997

Chamaecyparis obtusa (Siebold et Zucc.) Endl. var. obtusa partially documented - 1997; fully documented - 2013

Chamaecyparis pisifera (Siebold et Zucc.) Endl. fully documented - 2013

Cryptomeria japonica (Thunb. ex L. f.) D. Don var. japonica fully documented - 1997, 2013

Cryptomeria japonica var. radicans Nakai partially documented - 1997; fully documented - 2013

Juniperus chinensis L. (s. 1.) fully documented - 2013

Juniperus communis L. var. nipponica (Maxim.) E. H. Wilson fully documented -2013

Juniperus conferta Parl. fully documented - 2013

Juniperus lutchuensis Koidz. partially documented - 2013

Juniperus procumbens (Siebold ex Endl.) Miq. fully documented -2013

Juniperus rigida Siebold et Zucc. fully documented - 2013

Juniperus sargentii (A. Henry) Takeda ex Nakai fully documented - 1997

Juniperus taxifolia Hook. et Arn. partially documented - 2013

Juniperus tsukusiensis Masam. fully documented - 1997, 2013

Larix kaempferi (Lamb.) Carrière partially documented - 1997; fully documented - 2013

Nageia nagi (Thunb.) Kuntze fully documented -2013

Picea alcoquiana (Veitch ex Lindl.) Carrière fully documented - 1997

Picea alcoquiana var. reflexa partially documented - 2013

Picea glehnii (F. Schmidt) Mast. fully documented - 1997

Picea jezoensis (Siebold \& Zucc.) Carrière var. jezoensis fully documented - 1997

Picea jezoensis var. hondoensis (Mayr) Rehder partially documented - 1997; fully documented - 2013 
Picea koyamae Shiras.

fully documented - 2013

Picea maximowiczii Regel ex Mast.

fully documented -2013

Picea torano (Siebold ex K. Koch) Koehne

partially documented - 1997; fully documented - 2013

Pinus amamiana Koidzumi

fully documented - 2013

Pinus densiflora Siebold et Zucc. var. densiflora

fully documented - 1997, 2013

Pinus koraiensis Siebold et Zucc.

partially documented - 2013

Pinus luchuensis Mayr

fully documented - 1997

Pinus parviflora Siebold \& Zucc.

fully documented -2013

Pinus parviflora var. pentaphylla (Mayr) A. Henry

fully documented - 1997

Pinus pumila (Pall.) Regel

partially documented - 1997; fully documented - 2013

Pinus thunbergii Parl.

partially documented - 1997; fully documented - 2013

Podocarpus macrophyllus (Thunb.) Sweet

partially documented - 1997; fully documented - 2013

Pseudotsuga japonica (Shiras.) Beissn.

fully documented - 1997, 2013

Sciadopitys verticillata (Thunb.) Siebold et Zucc.

partially documented - 1997; fully documented - 2013

Taxus cuspidata Siebold et Zucc. var. cuspidata

fully documented - 1997

Taxus cuspidata var. nana Hort. ex Rehder fully documented - 1997, 2013

Thuja standishii (Gordon) Carrière partially documented - 1997; fully documented - 2013

Thujopsis dolabrata (Thunb. ex L. f.) Siebold et Zucc. partially documented - 1997; fully documented - 2013

Torreya nucifera (L.) Siebold et Zucc. var. nucifera fully documented - 1997, 2013

Torreya nucifera var. radicans Nakai fully documented - 1997, 2013

Tsuga diversifolia (Maxim.) Mast.

partially documented - 1997; fully documented - 2013

Tsuga sieboldii Carrière

fully documented - 1997, 2013 